\title{
Lobizon and Navira, two new genera of wolf spiders from Argentina (Araneae: Lycosidae)
}

\author{
LUIS N. PIACENTINI \& CRISTIAN J. GRISMADO \\ División Aracnología, Museo Argentino de Ciencias Naturales "Bernardino Rivadavi” a, Av. Angel Gallardo 470, C1405DJR, Buenos
} Aires, Argentina. E-mail: piacentini@macn.gov.ar, grismado@macn.gov.ar

\begin{abstract}
Two new genera in the family Lycosidae Sundevall, 1833 from Argentina are proposed. Lobizon gen. nov. comprises five species: Lobizon corondaensis (Mello-Leitão, 1941) comb. nov. (type species), L. minor (Mello Leitão, 1941) comb. nov., and L. humilis (Mello-Leitão, 1944) comb. nov., all these with a wide distribution in Argentina, and two new species: L. ojangureni sp. nov. from the montane forests of Northwestern Argentina, and L. otamendi sp. nov. from the northeastern Buenos Aires Province. The monotypic Navira gen. nov. is erected for N. naguan sp. nov. from Córdoba and San Luis Provinces. Trochosippa anomala (Mello-Leitão, 1945) and Alopecosa unguiculata Mello-Leitão, 1944 are considered junior synonyms of L. corondaensis and L. humilis respectively. A putative synapomorphy uniting the two genera is the massive, greatly elongated terminal apophysis which is grooved along its length. The subfamily placement of the two new genera is briefly discussed, and it is concluded that they probably belong to the Artoriinae Framenau, 2007 or Venoniinae Lehtinen \& Hippa, 1979.
\end{abstract}

Key words: Artoriinae, Venoniinae, taxonomy, South America

\section{Introduction}

The family Lycosidae Sundevall, 1833, usually known as wolf spiders, is one of the most diverse groups of spiders, with 2339 described species in 110 genera (Platnick 2009). It comprises small to large, three-clawed, ecribellate, mainly hunting spiders that occur in significant numbers in virtually every terrestrial habitat (Murphy et al. 2006). Wolf spiders are easily recognised by the characteristic arrangement of the eyes in three rows (4:2:2), the absence of a retrolateral tibial apophysis on the male palp and their typical behaviour of carrying the eggsac attached to the female spinnerets and transporting the newly hatched spiderlings on the female opisthosoma for several days before dispersing (e.g., Dondale 2005).

Most lycosids are active hunters that use a stalking and ambushing strategy, using vision to detect their prey, but some genera, for example those in the subfamily Sosippinae Dondale, 1986, spin sheet webs for prey capture (e.g., Santos \& Brescovit 2001). This behaviour was traditionally considered plesiomorphic for the family, but this presumption was recently questioned (Murphy et al. 2006).

A considerable number of investigations have covered several aspects of the biology of wolf spiders: courtship, mating, habitat preference, and general behaviour, mainly in Holarctic species (see Dondale 2005 for references), and also in a few Neotropical representatives (e.g., Costa 1975, 1979; Aisenberg \& Costa 2005; Aisenberg et al. 2008). Only few studies have investigated behavioural patterns in a phylogenetic context (e.g., Murphy et al. 2006; Stratton et al. 1996; Stratton et al. 2004).

The knowledge of the taxonomy of the group is far from satisfactory. The principal reasons for systematic problems at the genus level are due to the morphological conservatism of the Lycosidae and the lack of useful characters to define and separate genera. 
Although the generic placement of the Western Palearctic lycosids seems to be well established (e.g., Heimer \& Nentwig 1991) and some Nearctic (e.g., Brady 1980, Brady \& Mc Kinley 1994; Dondale \& Redner 1978, 1979, 1983a, b; Kronestedt 1975, 1981, 1986, 1987, 1993; Vogel 2004) and few African genera (Alderweireldt 1991, 1996, 1999; Alderweireldt \& Jocqué 2005; Russell-Smith 1982) have been recently revised, many of the remaining lycosid species seem to be misplaced. For example, a revision and phylogenetic analysis of the New Zealand lycosid fauna (Vink 2002; Vink et al. 2002) showed that all but one described species were wrongly placed in Holarctic genera.

In the Southern Hemisphere, early taxonomists usually placed lycosid species into genera familiar to them, such as Lycosa Latreille, 1804, Pardosa C. L. Koch, 1847b, Alopecosa Simon, 1885, and Trochosa C. L. Koch, 1847a. Later on, the confusion increased with the contributions of Roewer (1951, 1955, 1959, 1960), who erected 65 lycosid genera, usually with short descriptions, based on somatic and generally highly variable characters.

In the recent years, the faunas of Australia and New Zealand were revised and new genera have been created for many endemic species (Framenau 2002, 2005, 2006a-e, 2007; Framenau \& Baehr 2007; Framenau \& Vink 2001; Yoo \& Framenau 2006). In South America, however, the work progressed at a slower pace. Casanueva (1980) revised the lycosids from Chile, Capocasale (2001a, b) solved some taxonomic problems, and Capocasale (1991) and Santos \& Brescovit (2001) contributed with studies on the webspinning genus Aglaoctenus Tullgren, 1905. However, these studies did not solve the majority of inconsistencies in the generic placement of most of the South American species. Only recently, Álvares (2006) carried out a major taxonomic revision of the subfamily Lycosinae Sundevall, 1833 in Brazil and adjacent countries, however his thesis remains unpublished. Miguel Simó (pers. comm.) is currently studying the subfamily Allocosinae Dondale, 1986.

We focused our studies on the small Argentine species described by Mello-Leitão in the genera Pardosa and Alopecosa (Mello-Leitão 1941, 1944, 1945): Pardosa corondaensis Mello-Leitão, 1941, Alopecosa anomala Mello-Leitão, 1945, A. minor Mello-Leitão, 1941, A. humilis Mello-Leitão, 1944 and A. unguiculata Mello-Leitão, 1944. As occurred with the Australasian species, these are clearly misplaced in Holarctic genera. With C. F. Roewer's subsequent transfers, some ended up in the putatively African genera Trochosippa Roewer, 1960 and Pardosella Di Caporiacco, 1939.

We have examined the type series, museum and newly collected specimens from several regions of Argentina, and have provided data to propose the taxonomic changes that are presented in this paper. The taxonomic history of these species is summarised, and a brief discussion on their subfamily placement is presented.

Taxonomic background: the subfamilies of the Lycosidae. As is shown below (see Discussion), the subfamily placement of the two genera here described is contentious. Since the work of Dondale (1986), the subfamilies Sosippinae, Lycosinae, Pardosinae Simon, 1898 and Allocosinae seem to be reasonably well established (see diagnoses in Dondale 1986: 330-331). The same is true for the Zoicinae Lehtinen \& Hippa, 1979 (Lehtinen \& Hippa 1979; Yoo \& Framenau 2006) and two subfamilies erected by Zyuzin (1985), Evippinae Zyuzin, 1985 and Wadicosinae Zyuzin, 1985.

However, the situation is still unclear, as was recently demonstrated by a molecular analysis of Murphy et al. (2006), which found strong support for some currently valid subfamilies, but not for others, of which the status needs to be re-assessed (e.g., the Pardosinae). Murphy et al. (2006) also found that many genera as currently defined are not monophyletic.

Dondale (1986) modified the original diagnosis of the Venoniinae, and defined the subfamily by the following characters: median apophysis enlarged and oriented longitudinally on genital bulb, terminal apophysis small, situated distally on bulb and functioning as conductor, and embolus small, situated distally. However, this diagnosis of the Venoniinae seemed to be based mainly on Palaearctic and Nearctic representatives, in particular Pirata Sundevall, 1833, and did not reflect the pedipalp configurations found in Venonia Thorell, 1894, and other genera usually considered venoniines, such as Anomalosa Roewer, 1960 and Allotrochosina Roewer, 1960 (Yoo \& Framenau 2006; Framenau 2006d; Vink 2002). 
Zyuzin (1993) created a new subfamily, Piratinae Zyuzin, 1993, for Pirata and allied genera (Piratula Roewer, 1960, Aulonia C. L. Koch, 1847a, Hygrolycosa Dahl, 1908), diagnosed by the functional conductor combined with a short, thin embolus in a common sickle-shaped complex resting in a deep and narrow ascending tegular groove. In the same year, Alderweireldt \& Jocqué (1993) proposed the Tricassinae Alderweireldt \& Jocqué, 1993 for Tricassa deserticola Simon, 1910, a peculiar psammophilous lycosid from Namibia and South Africa.

A phylogenetic study of Venonia and allied genera (Yoo \& Framenau, 2006) led to the resurrection of the subfamily Zoicinae and, consequently, the concept of Venoniinae was returned to that of Lehtinen \& Hippa (1979).

Recent molecular analyses are relevant with respect to subfamily delimitations within the Lycosidae. These studies failed to corroborate some of the previous subfamilies, especially when faunas from other regions than the Holarctic are considered (Zehethofer \& Sturmbauer 1998; Vink et al. 2002; Murphy et al. 2006). The latter study used three molecular markers from a more comprehensive sampling comprising 70 species from more than 25 genera from most biogeographic regions. In their phylogenetic analyses, they obtained a monophyletic group of Australasian species, which later led to the creation of the subfamily Artoriinae Framenau, 2007, diagnosed by the presence of a basoembolic apophysis in the male pedipalp and considered the sister group to the Lycosinae and Pardosinae combined (Murphy et al. 2006; Framenau 2007).

\section{Material and methods}

Specimens and figures. Specimens are deposited in the Arachnological Collection of the Museo Argentino de Ciencias Naturales "Bernardino Rivadavia", Buenos Aires (MACN-Ar, Cristina L. Scioscia), and Museo de La Plata (MLP, Luis Pereira). Drawings were made using a camera lucida mounted on a Leitz stereoscopic microscope or an Olympus BH-2 compound microscope. The internal genitalia were cleared in clove oil for observation and in some cases (non type specimens), digested with warm $10 \% \mathrm{KOH}$ solution to dissolve soft tissues. The photographs of the preserved specimens were taken with a Nikon DXM 1200 digital camera mounted on a Nikon SMZ1500 stereoscopic microscope. Scanning electron micrographs were taken under high vacuum with a FEI XL30 TMP after critical point drying and Gold-Palladium coating.

Abbreviations and terminology. The macrosetae notation follows Framenau (2002). The names of the sclerites of the male palp follow, when possible, Framenau (2002), with some terms introduced in Yoo \& Framenau (2006) (e.g., "clypeal condyle"). We also reinterpreted some structures: we refer to the "retrolateral tegular lobe" (RTL) as the retrolateral portion of the tegulum delimited by the deep ventral incision (displaced retrolaterally in some species). We use the terms "embolic division" and "palea region" following Sierwald (2000). We refer to the "embolic division" as the complete set of distal structures of the palea region (embolic division $=$ palea region + embolus + terminal apophysis).

The flattened longitudinally directed apophysis (MA in Figs 5-8) does not seem to have its origin directly at the tegulum, but rather at an unsclerotised area of the bulb, hence we call it "median apophysis" (MA, following the criterion of Coddington, 1990: p. 10, for Araneoclada) rather than the more ambiguous "tegular apophysis".

The nomenclature of the female genital elements follows Sierwald (1989, 2000), i.e., the copulatory openings (CO) lead, through the copulatory ducts (CD), to the spermathecae, which have a basal part (base of spermatheca, BS), a rounded distal receptacle (head of spermatheca, HS, recognised by its pores) and a tube connecting both parts (stalk of spermatheca, SS). The copulatory duct also branches into a dorsal additional receptacle, the "vulval chamber (VC), which finally, terminates in the fertilisation duct (FD). Other abbreviations are as follows: dictynoid pore (DP), embolus (E), opisthosoma length (OL), prosoma height $(\mathrm{PH})$, prosoma length (PL), prosoma width (PW), taken in the fovea zone, subtegulum (ST), tegulum (T), terminal apophysis (TA). All measurements are expressed in millimeters. 
We report GPS coordinates of the localities when available; otherwise, we provide approximate coordinates (denoted with "ca.") calculated with Google Earth (http://earth.google.com) from label data.

\section{Discussion}

Homologies of male copulatory bulb structures. Our interpretation of some characters of the copulatory bulb structures requires some explanation. For the terms "palea" or "palea region" we follow the terminology of Sierwald (2000), who proposed that the large membranous sac at the base of the embolus of Sosippus Simon, 1888 consists of sclerotised and membranous parts similar to the developed palea in other lycosids. Consequently, she labeled the first part of the embolic division as the "palea region". We found a similar pattern in the two genera here described: we do not see any clearly differentiated structure basally of the embolus and follow her terminology. A similar feature also occurs in Venonia (Yoo \& Framenau, 2006: 677) but these authors opted to call this much reduced palea "embolic division", which carries an "embolic hood" and an "embolic apophysis".

Both Lobizon gen. nov. and Navira gen. nov. have a broad lamellar outgrowth of the embolic base that might be considered homologous to the basoembolic apophysis (BEA) of artoriines (note that in Diahogna Roewer, 1960 and Tetralycosa Roewer, 1960 the BEA is thin and lamellar, not strongly sclerotised as in the other Artoriinae (Framenau 2006d, Framenau et al. 2006)). On the other hand, the median apophysis (MA) of Lobizon gen. nov. and Navira gen. nov. are flattened and weakly sclerotised, more closely resembling those of Anomalosa and Venonia (Venoniinae) than the massive and complex MA of artoriines, which has a variable shape: branched, acute or spoon-shaped and always strongly sclerotised (Framenau 2002, 2005, 2007). There is also a possible homology of structures such as the "embolic hood", the "embolic apophysis" or "apical process of embolic division" of Venonia and Allotrochosina with the BEA of artoriines.

Hypothesis on the subfamily placement of Lobizon gen. nov. and Navira gen. nov. The longitudinal median apophysis of Lobizon gen. nov. and Navira gen. nov. excludes Lycosinae, Allocosinae, Piratinae, Wadicosinae, and Zoicinae. The large terminal apophysis excludes them from Tricassinae and Sosippinae, and the poorly developed palea region and the lack of a transversal depression on the carapace excludes them from Pardosinae and Evippinae, respectively.

Of the remaining subfamilies, Venoniinae and Artoriinae share with Lobizon gen. nov. and Navira gen. nov. the general orientation and shape of the elements of the bulb, especially the incised or divided tegulum and the longitudinally directed median apophysis (see Figs 3,6). Both subfamilies were found to be reasonably well supported by Vink et al. (2002) and Murphy et al. (2006).

The subfamily Artoriinae was diagnosed by having a basoembolic apophysis, but no explicit morphological synapomorphies were proposed for the Venoniinae as delimited by Lehtinen \& Hippa (1979) and Yoo \& Framenau (2006). If the broad lamellar outgrowth of the embolus found in Lobizon gen. nov. and Navira gen. nov. is interpreted as a BEA, this would favour their inclusion in the Artoriinae. Navira gen. nov. and, especially, Lobizon gen. nov. are superficially similar in body shape to the smaller species of Anoteropsis L. Koch, 1878 and Artoria Thorell, 1877, contrasting the gracile body and long PLS found in Venonia and relatives. On the other hand, the median apophysis in Lobizon gen. nov. and Navira gen. nov. is flattened and weakly sclerotised, as found in the venoniines Venonia and Anomalosa, and unlike the more sclerotised sclerite found in Artoriinae.

The uncertain subfamily placement of the genera here described is not surprising given the current knowledge of the phylogeny of lycosids. As noted by Murphy et al. (2006), there is need for more morphological and molecular studies including additional South American taxa. Genera never treated in a phylogenetic context include Agalenocosa Mello-Leitão, 1944, the African Trabea Simon, 1876 and Tricassa as well as the Nearctic Trebacosa Dondale \& Redner, 1981 and Trabeops Roewer, 1959. Only by extending the geographic coverage of the studied groups we will be able to approach a realistic scenario of the relationships among wolf spiders. 


\section{Taxonomy}

\section{Family Lycosidae Sundevall, 1833}

\section{Lobizon gen. nov.}

Type species. Pardosa corondaensis Mello-Leitão, 1941.

Etymology. The "Lobizón" is the Argentine version of the widespread folkloric myth of the werewolf or lycanthrope (a man becoming a wolf at night during the full moon). This legend is very popular in rural areas of Argentina. The generic name is an elliptical allusion to the wolf spiders. Gender masculine.

Diagnosis. The only putative synapomorphy proposed for Lobizon gen. nov. is the conspicuous retrolateral patch of erect setae on the male palpal femur (Fig. 79, less dense in L. otamendi sp. nov.). Otherwise, this genus is distinguished by the following combination of characters: only two teeth on the cheliceral retromargin in both sexes (Fig. 81); males with partially divided tegulum, covering the whole subtegulum in the unexpanded palp; median apophysis enlarged and oriented longitudinally, flattened and weakly sclerotised, embolus very long resting in a very large and complex terminal apophysis grooved along all its length, and a broad lamellate outgrowth on the base of embolus (Figs 3-8, 23, 25, 26, 41, 43, 44, 57-58, 67-68). Females differ from those of Navira gen. nov. by having well developed vulval chambers (Figs 10, 12) and by lacking the transverse pattern of bands on the opisthosoma.

Description. Small wolf spiders (TL, 2.82-5.96 mm). Females larger than males.

Dorsal shield of prosoma brown with a light brown median band and submarginal bands (except $L$. otamendi sp. nov., with marginal bands). Eyes surrounded by black area. Dorsum of opisthosoma brown to dark olive-grey, with light yellow lanceolate mark in the cardiac area and a pattern of spots laterally and posterior to the cardiac mark. Carapace longer than wide, dorsal line straight in lateral view (Figs 17-18). Caput flanks in frontal view steep in males, but a gentle slope in females.

Four long bristles anterior of the AER. AME larger than ALE, AER procurved in anterior view. Prominent clypeal condyle, especially in males. Chelicerae with three promarginal and two retromarginal teeth. Leg formula IV > I > II > III or IV > I > III > II. Femur I with three dorsal spines, tibia I with three ventral pairs of spines.

The male palp of Lobizon gen. nov. species has an inconspicuous palea region (Fig. 41) and a relatively long embolus, especially L. corondaensis and L. ojangureni sp. nov. (Figs 26 and 58), with a prolateral or prolateral-distal origin. The embolus describes a strong counter-clockwise curve (left palp, ventral view) and rests terminally on the terminal apophysis, that is always a large, grooved and complex sclerite with a pointed or curved tip (Figs 4, 7). At the embolic base, there is a broad lamellar outgrowth (Figs 6-8, 23, 41). The tegulum has a ventral deep incision delimiting a large retrolateral lobe, which has a membranous distal portion and sometimes a small ventral protrusion with several small peaks (PP, Figs 8, 43, 67). The median apophysis is flattened and longitudinally oriented, sometimes scarcely surpassing the tegular border, subtegulum not visible in unexpanded palps.

Epigyne variable, usually a median plate with a shallow septum (Fig. 9) or without septum (Fig. 11), with a median lip directed posteroventrally (also variable, from large to inconspicuous) and copulatory openings on the lateral margins. Internally, they have the typical structures known in lycosids (see above, Material and methods): the copulatory ducts are medium to long, describe a pronounced curve to end in the base of the spermathecae. The spermathecal heads are always in medial position, while the vulval chambers are usually large, sometimes pedunculate.

Remarks. The species here assigned to Lobizon do not fit in the pardosine genus Pardosa, nor in the lycosine genus Alopecosa, where they were originally placed, because they lack the morphological features well known of these Holarctic genera; see, for example, Dondale (1986, 2005); Dondale and Redner (1979); Kronestedt $(1975,1981)$ and Vogel (2004). 
Roewer (1960) transferred Alopecosa anomala (here considered a junior synonym of $P$. corondaensis) and Alopecosa minor to his genus Trochosippa Roewer, 1960, and Pardosa corondaensis to Pardosella di Caporiacco, 1939, both containing mostly African species. The type species of Trochosippa is Lycosa urbana meruensis Lessert, 1926, which has an epigyne and a palp typical of the subfamily Lycosinae (e.g., the epigyne with a median septum as an inverted " $\mathrm{T}$ " and a transverse median apophysis, with a spur directed ventrally; Lessert 1926: figs 6B and 7B). Hence, the placement of the Argentine species in Trochosippa is incorrect. Similarly, the type species of the African genus Pardosella (P. zavattarii di Caporiacco, 1939) has an epigyne typical of a pardosine (e.g., an anteriorly elongate septum; di Caporiacco, 1939: fig. 9a).

Composition. Five species, L. corondaensis (Mello-Leitão, 1941), L. minor (Mello-Leitão, 1941), L. humilis (Mello-Leitão, 1944). L. ojangureni sp. nov., and L. otamendi sp. nov.

Distribution. Northern and central Argentina, from Jujuy, Salta and Misiones to Buenos Aires and Mendoza (Figs 83-86).

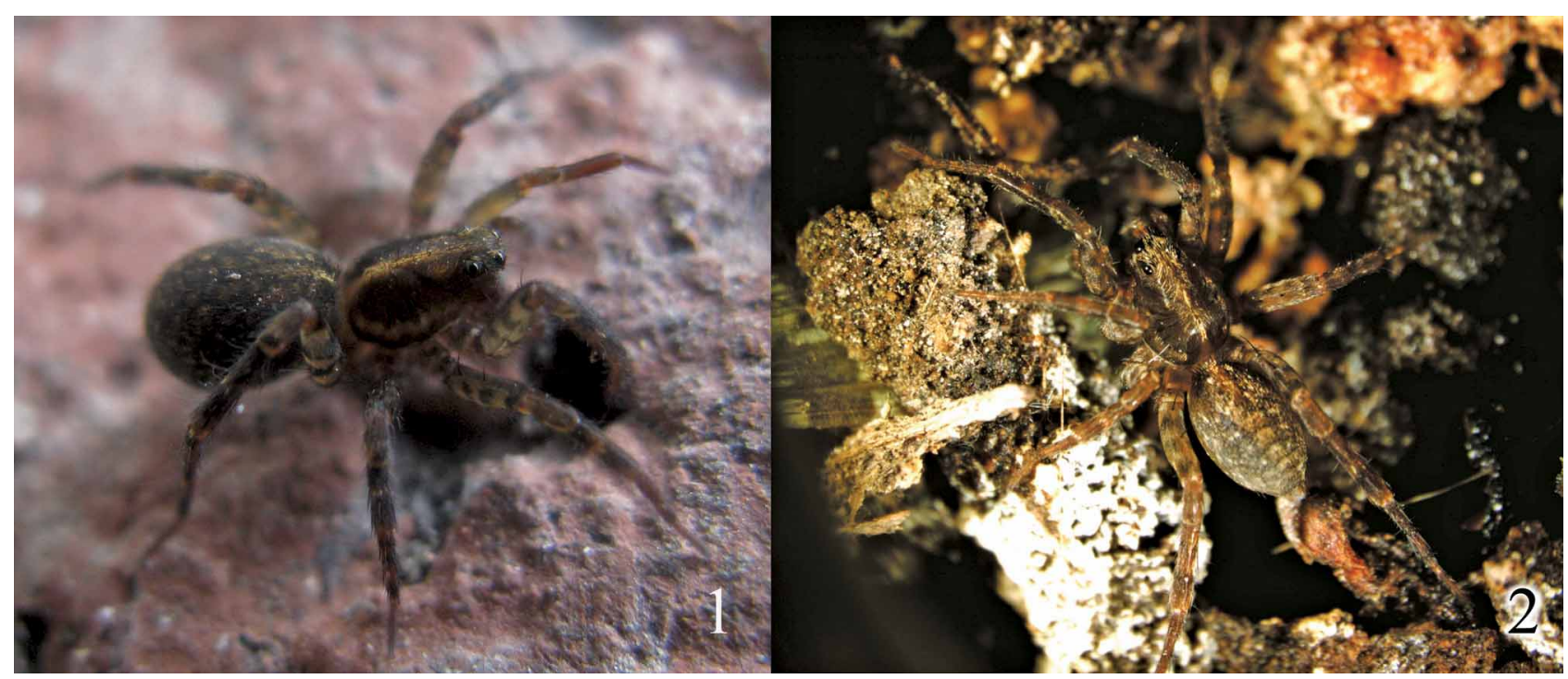

FIGURES 1-2. Lobizon gen. nov., photographs of life specimens. 1, Lobizon ojangureni sp. nov., female from Parque Nacional Calilegua; 2, Lobizon corondaensis (Mello-Leitão), male from San Rafael.

Lobizon corondaensis (Mello-Leitão, 1941) comb. nov.

(Figs 2, 3-5, 9-10, 15-32, 83)

Pardosa corondaensis Mello-Leitão 1941: 209, fig. 10; female holotype from Argentina, Santa Fe, Coronda, M. Birabén, in MLP 15092, examined.

Pardosella corondaensis.- Roewer 1955: 196.

Alopecosa anomala Mello-Leitão 1945: 246, fig. 29; female holotype from Argentina, Misiones, San Ignacio, deposited in MLP 16450, examined. New synonymy.

Trochosippa anomala.- Roewer 1955: 303.

Other material examined. ARGENTINA: Jujuy: Parque Nacional Calilegua, Aguas Negras, 1100 m, 57.VIII.1997, Ramírez M. \& Compagnucci L., 1 female, 2 immatures (MACN-Ar 16213); same data, 1 female,

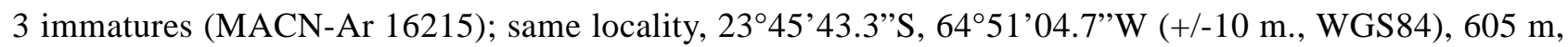
06-11.XII.2008, Grismado C., Izquierdo M., Labarque F., Rubio G., Burger M., Michalik P., Carrera P., Ojanguren A. \& Mattoni C., nocturnal hand collecting, 3 males, 2 females (MACN-Ar 18325); same data, 1 female (MACN-Ar 18326); same locality, Sendero "La Herradura" 2345'25.6”S, 6451'04.7’W, 27.I.2009, Izquierdo M., Zapata L. \& Akmentins M., diurnal hand collecting, 1 female (MACN-Ar 18327). Salta: Finca

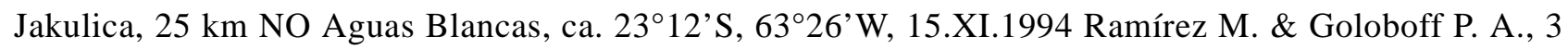

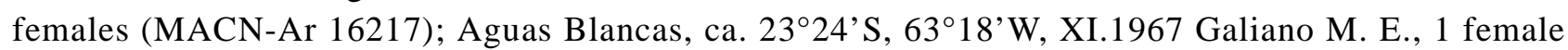


(MACN-Ar 16216). Mendoza: San Rafael: Camping Rayuela, 3447’41.31'S, 69²7’01.49”W, 0411.II.2008, Piacentini L. \& Fernandez C., 1 male. Chaco: Parque Nacional Chaco, Laguna Carpincho, $26^{\circ} 47^{\prime} 02.8^{\prime \prime S}, 59^{\circ} 37^{\prime} 41.2^{\prime \prime W}$, alt. 70 m., Grismado C., Compagnucci L. \& Galvani G., 11-13.XI.2007, sifting litter in forest, 5 males, 6 females, 2 inmmatures (MACN-Ar 13618); same locality, 26.II.2004, Grismado C., Ojanguren A., Labarque F. \& Compagnucci L., 1 female (MACN-Ar 16235). Misiones: Parque Provincial Urugua-í, Sendero Dr. Rolón, ca. 2549'S, 5401'W, 10.XII.1999, Szumik C., Chalup \& Winkler, 1 male (MACN-Ar 16229); same locality and collectors, 11.XII.1999, 1 female (MACN-Ar 16228); same locality and collectors, no date, 1 female (MACN-Ar 16230). Corrientes: San Cayetano, Estación Biológica de Corrientes (EBCo), 27³3'03.9'’S, 5840'40.2”W, alt. 48 m, Grismado C., Piacentini L., Izquierdo M., Compagnucci L. \& Martínez J., 5-10.XI.2007; forest, under logs; Parque Nacional Mburucuyá (2758'$26^{\circ} 05^{\prime} \mathrm{S}, 57^{\circ} 59^{\prime}-58^{\circ} 08^{\prime} \mathrm{W}$ ), specimens examined by Rubio et al. (2008, as Trochosippa anomala), 16 males, 7 females; Mburucuyá, ca. 27²9'S, 5849’W,15.XII.(year not given); Winkler, 1 female, 1 immature (MACN-Ar 16234). Santa Fe: Las Gamas, 20 km W Vera, ca. 29²5'S, 60²1'W, 27.X.1994, Ramírez M. \& Faivovich J., 2 females, 1 immature (MACN-Ar 16218); Colonia Mascías, ca. 3047'S, 6001'W,XI.1942, Viana J. M., 2 females (MACN-Ar 16221). Entre Ríos: Arroyo Gualeyán y Ruta Nacional 14, near Gualeguaychú, ca. 3300'S, 58³6’W, 2.XI.1996, Ramírez M., 1 male (MACN-Ar 16214). Buenos Aires: no precise locality, 1966, Pallares, 1 male (MACN-Ar 16223); Sierras de Olavarría, ca. 3650'S, 60¹3'W, 36.XII.1992, Ramírez M., 1 male (MACN-Ar 16219); Río Luján, ca. 34¹6’S, 5854’W, 30.X.1990, Ramírez M., 1 male (MACN-Ar 16231); Otamendi, ca. 34²13'S, 58 54'W, 14.XII.1997, Fuentes B., 1 male (MACN-Ar 16224); Reserva Natural Otamendi, ca. 34²13'S, 5854’W, 9.I.1998 Fuentes B. \& di Iorio O., 1 male (MACNAr 16226), same locality and collectors, 15.XI.1997, 3 males (MACN-Ar 16227); locality and collectors, 25.X.1997, 1 male (MACN-Ar 16225); San Fernando, ca. 34²6'S, 58³3'W, XII.2002, Piacentini L., 3 females, 1 immature (MACN-Ar 16233); same data, 2 males (MACN-Ar 16222); Vuelta de Obligado, ca.

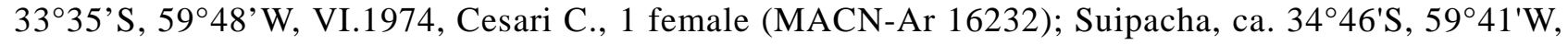
23.XI.2003, Piacentini L., 1 male (MACN-Ar 16220).

Diagnosis. Males of $L$. corondaensis resemble those of L. ojangureni sp. nov. by the relatively broad palp with very long embolus arising apically, but differ by the less excavated tegulum, and by the embolus that is shorter than in L. ojangureni sp. nov. (Figs 23, 25, 26). The epigyne of females has an approximately quadrangular field (similar to that of $L$. otamendi sp. nov.), with a shallow septum (only evident in the SEM images, see Fig. 9) and sclerotised lateral margins, parallel or convergent anteriorly (see variability in Figs 21, 27-31). Internally, L. corondaensis vulvae also resemble those of L. ojangureni sp. nov., but the copulatory ducts are less convoluted (Figs 10, 22, 24).

Description. Female (MACN-Ar 13618).

Dorsal shield of prosoma brown with grey radial pattern, light median band narrowing posteriorly and pale submarginal bands. Dorsal shield of prosoma covered with short brown setae; median band with few long black bristles from the fovea to the PLE; four long black bristles on the clypeal condyle anterior of AER. Sternum yellow, sparsely covered with brown bristles, more abundant on the margins. Labium dark grey. Chelicerae darker than labium, reddish-brown; covered with brown bristles. Opisthosoma dark olive grey; light yellow lanceolate mark on the cardiac area, followed and flanked by a series of light patches, more abundant in the posterior half; venter yellow with some dusk patches; spinnerets yellow. Legs brown with dark annulations; leg formula IV > I > II > III. Spination of leg I: femur: three dorsal, one apico-prolateral; tibia: three ventral pairs; metatarsus: three ventral pairs. Epigyne with an approximately quadrangular median field with a shallow septum, only evident in the SEM images (Fig. 9) and more or less parallel, lateral, sclerotised margins, straight or convergent in the centre (see variability in Figs 21, 27-31). Internally with rounded median spermathecae, vulval chambers developed, same dimensions as spermathecae, copulatory ducts long, running ectally to the spermathecae (Figs 10, 22, 24).

Male (MACN-Ar 13618).

Colouration and setae arrangement as in female. Leg formula IV > I > II > III. Spination of leg I, femur: three dorsal, one apico-prolateral; tibia: three ventral pairs and one prolateral; metatarsus: three ventral pairs 
and two prolateral spines (one in the middle and one distal). Palp with a dense patch of retrolateral bristles on the femur. Bulb with a very long embolus with apical origin, tegulum subdivided, terminal apophysis long with apex strongly curved retrodorsally, median apophysis laminar and longitudinally oriented. The sperm duct runs ventrally from the retrolateral to prolateral, describing a loop in the ventral side of the tegulum (Figs 25-26).

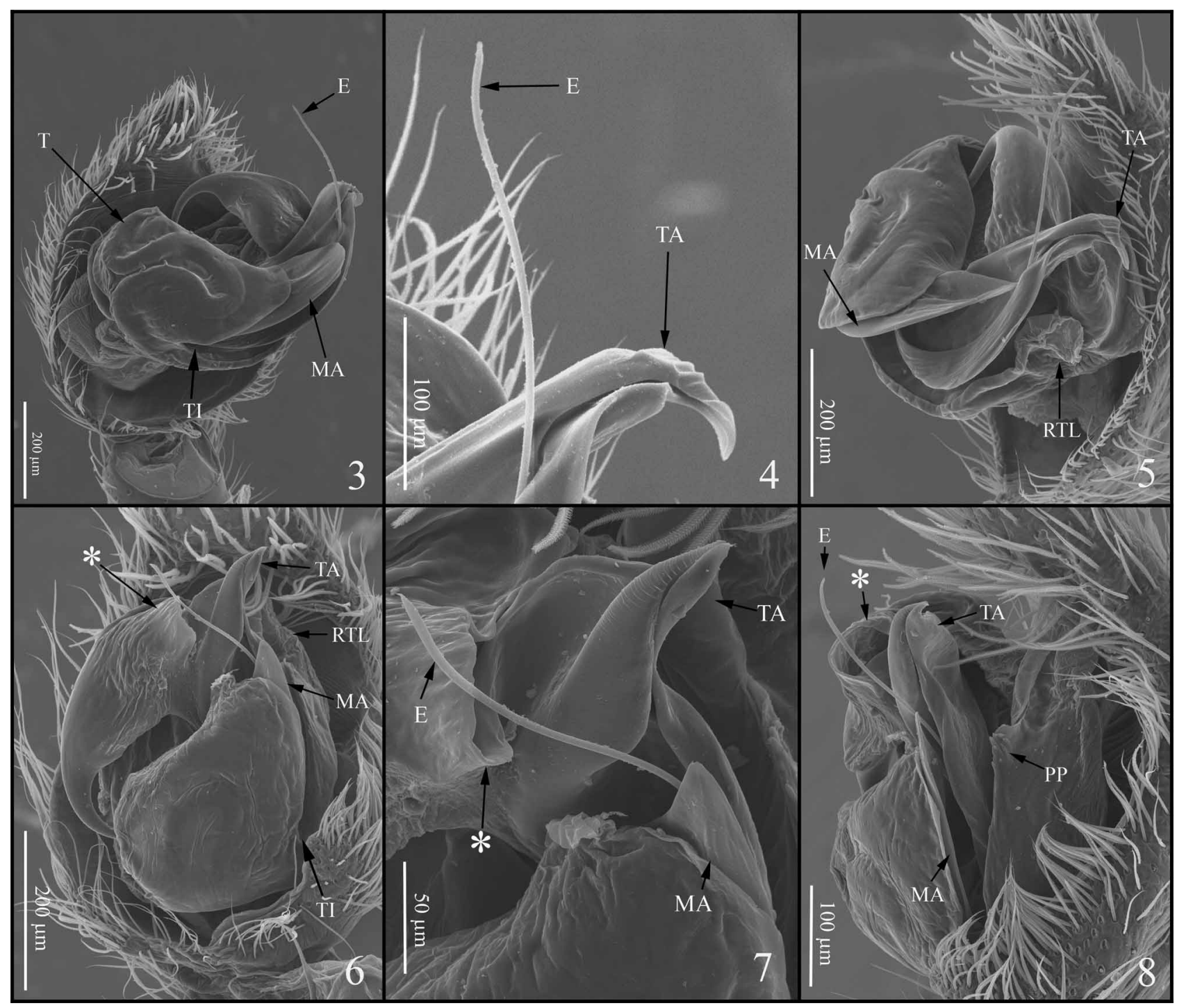

FIGURES 3-8. Expanded left male palp of Lobizon gen. nov.. 3-5, L. corondaensis (Mello-Leitão) from Parque Nacional Chaco, Laguna Carpincho (MACN-Ar 13618); 6-8, L. humilis (Mello-Leitão) from Don Torcuato (MACN-Ar 16277); 3, 6 ventral view; 4, 7, detail of terminal apophysis and embolus; 5, 8, retrolateral view. Asterisk: lateral outgrowth of the embolus, PP: peaked projection on RTL.

Measurements. Female, MACN-AR 13618 (male ,MACN-Ar 13618): TL 4.76 (3.63), PL 2.83 (2.00), PW 1.33 (1.47), PH 0.73 (0.70), OL 1.93 (1.63). Eyes: AME 0.09 (0.08), ALE 0.08 (0.06), PME 0.24 (0.31), PLE 0.18 (0.16). Row of eyes: AM 0.40 (0.38), PME 0.54 (0.54), PLE 0.64 (0.66). Sternum (length/width) 0.92/0.82 (0.97/0.83). Labium (length/width) 0.22/0.24 (0.67/0.77). Legs: length of segments (femur + patella/tibia + metatarsus + tarsus $=$ total length): Pedipalp $0.70+0.60+-+0.53=1.83, \mathbf{I} 1.23+1.70+0.93$ $+0.63=4.49$, II $1.23+1.57+0.93+0.57=4.30$, III $1.20+1.40+1.00+0.60=4.20$, IV $1.67+2.03+1.70$ $+0.70=6.10$ (Pedipalp $0.67+0.43+-+0.30=1.40, \mathbf{I} 1.25+1.67+1.05+0.58=4.55$, II $1.20+1.48+1.00$ $+0.58=4.26$, III $1.13+1.38+1.15+0.50=4.16$, IV $1.63+2.17+1.78+0.75=6.33)$. 


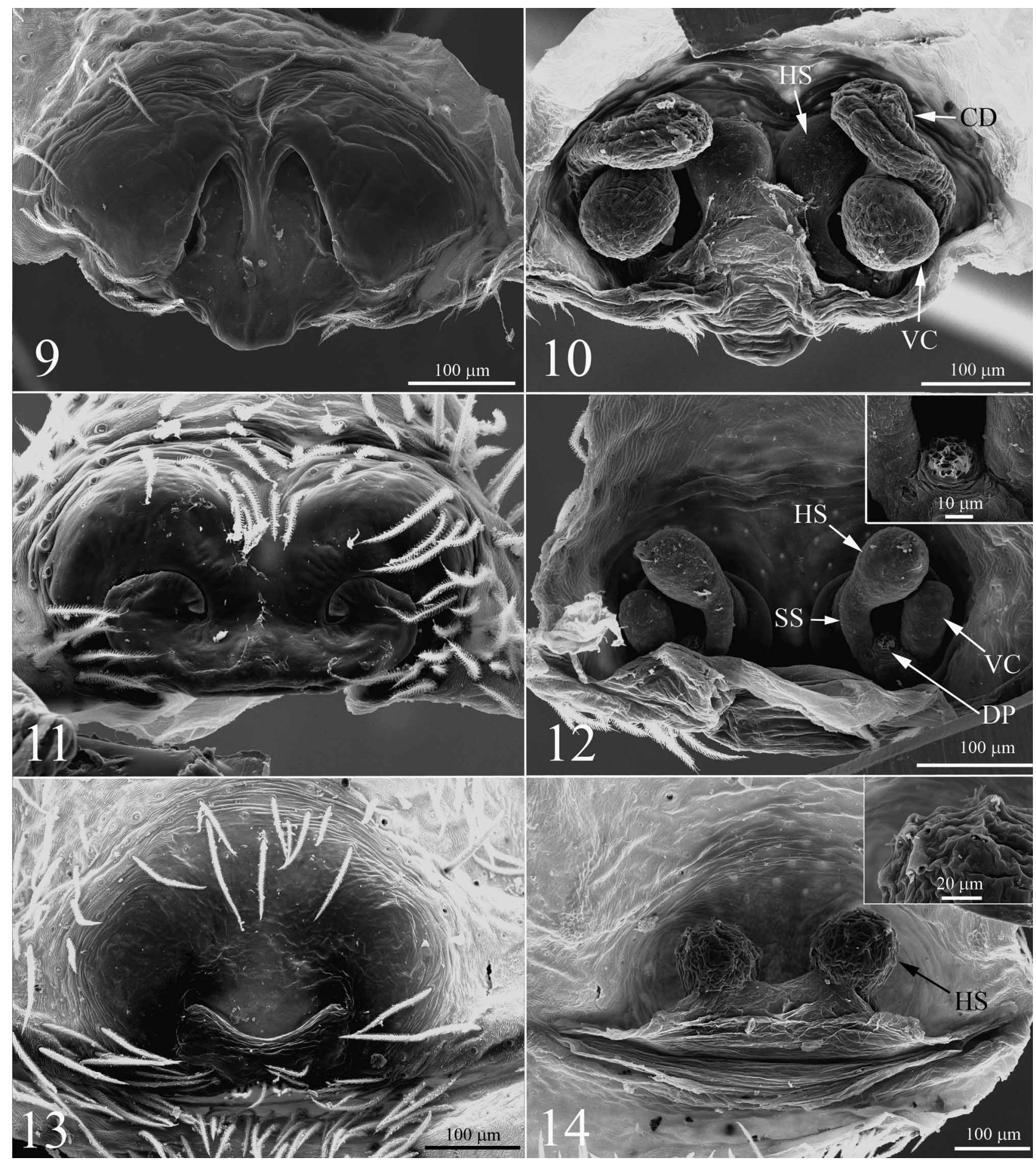

FIGURES 9-14. Female genitalia of Lobizon gen. nov. and Navira gen. nov.. 9-10, L. corondaensis (Mello-Leitão) from Parque Nacional Chaco, Laguna Carpincho (MACN-Ar 13618); 11-12, L. humilis (Mello-Leitão) from Reserva Natural Otamendi (MACN-Ar 16240); 13-14, Navira naguan sp. nov. from Bosque Alegre, $20 \mathrm{~km}$ de Carlos Paz (MACN-Ar 16282); 9, 11, 13, epigynes, ventral view; 10, 12, 14, vulvae, dorsal view. Upper right corner in Fig. 12, detail of the dictynoid pore; upper right corner in Fig. 14, detail of the pores of the head of right spermatheca.

Variation. Female (male) (range, mean \pm s.d.): TL $3.70-5.03,4.36 \pm 0.46$; CL $1.93-2.83,2.32 \pm 0.32$; CW $1.33-2.13,1.63 \pm 0.27 ; \mathrm{n}=10$ (TL $3.34-4.17,3.75 \pm 0.27$; CL $1.87-2.37,2.05 \pm 0.15$; CW $1.27-1.68$, $1.44 \pm 0.11 ; \mathrm{n}=10$ ). This species shows great variability in some genitalic and somatic characters. The lateral margins of the epigyne may be parallel, anteriorly convergent, or slightly curved, and the posterior lip may be 
conspicuous or shallow. This variability does not seem to be correlated to geographic distribution, because it occurs between specimens collected together in the same patch of leaf litter (Figs 27-31). Several males from Buenos Aires province have a conspicuous band of white setae on the anterior part of carapace (Fig. 32) and on the antero-dorsal section of the opisthosoma. These males have a less pronounced curvature in the ventral part of the sperm duct, visible by transparence in ventral view of the tegulum.

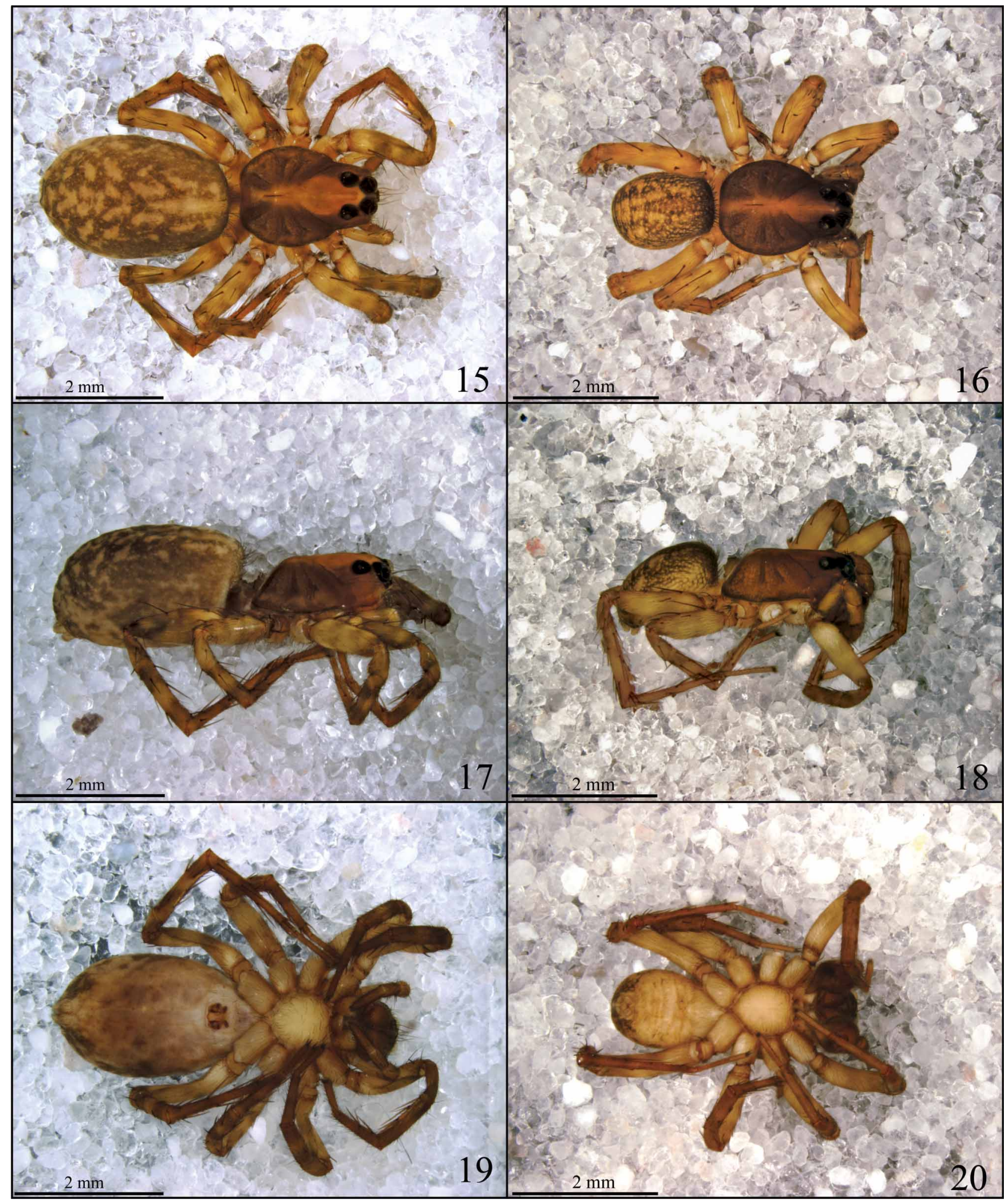

FIGURES 15-20. Lobizon corondaensis (Mello-Leitão), habitus of preserved specimens from Parque Nacional Chaco (MACN-Ar 13618). 15, 17, 19, female; 16, 18, 20, male; 15-16, dorsal; 17-18, lateral; 19-20, ventral. 

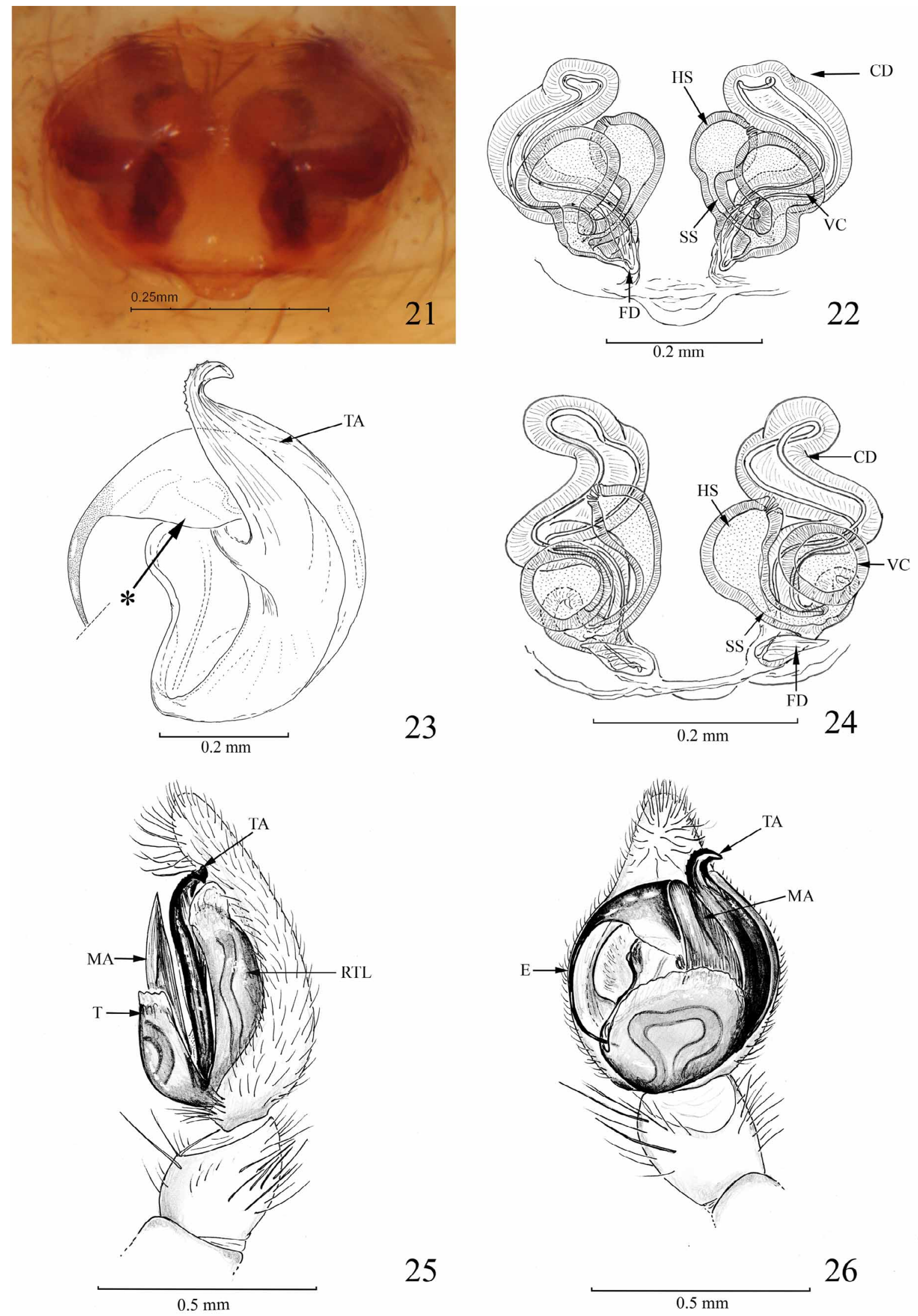

23

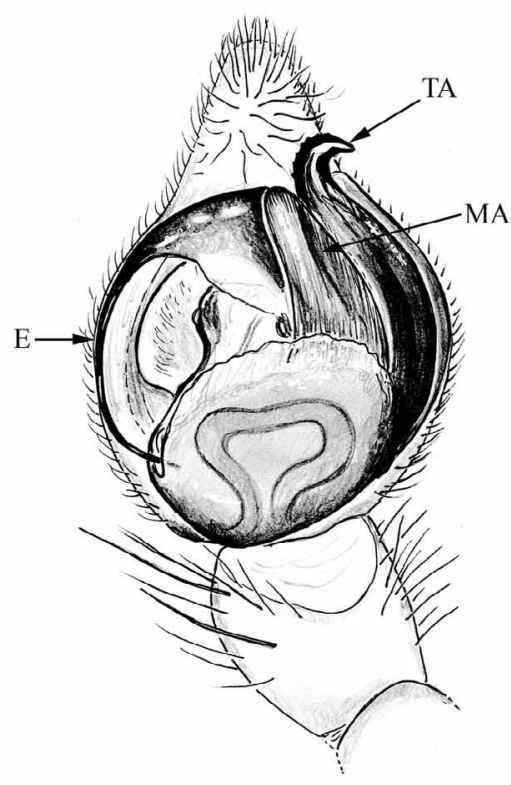

FIGURES 21-26. Genitalia of Lobizon corondaensis (Mello-Leitão). 21-22, female holotype of Pardosa corondaensis; 24, female from Parque Nacional Chaco (MACN-Ar 13618); 23, 25-26, male from Parque Nacional Chaco (MACN-Ar 13618); 21, epigyne, ventral; 22, 24, vulva, cleared, dorsal; 23, dissected embolic division (asterisk: lateral outgrowgth of the embolus); 25, left palp, retrolateral; 26, same, ventral. 


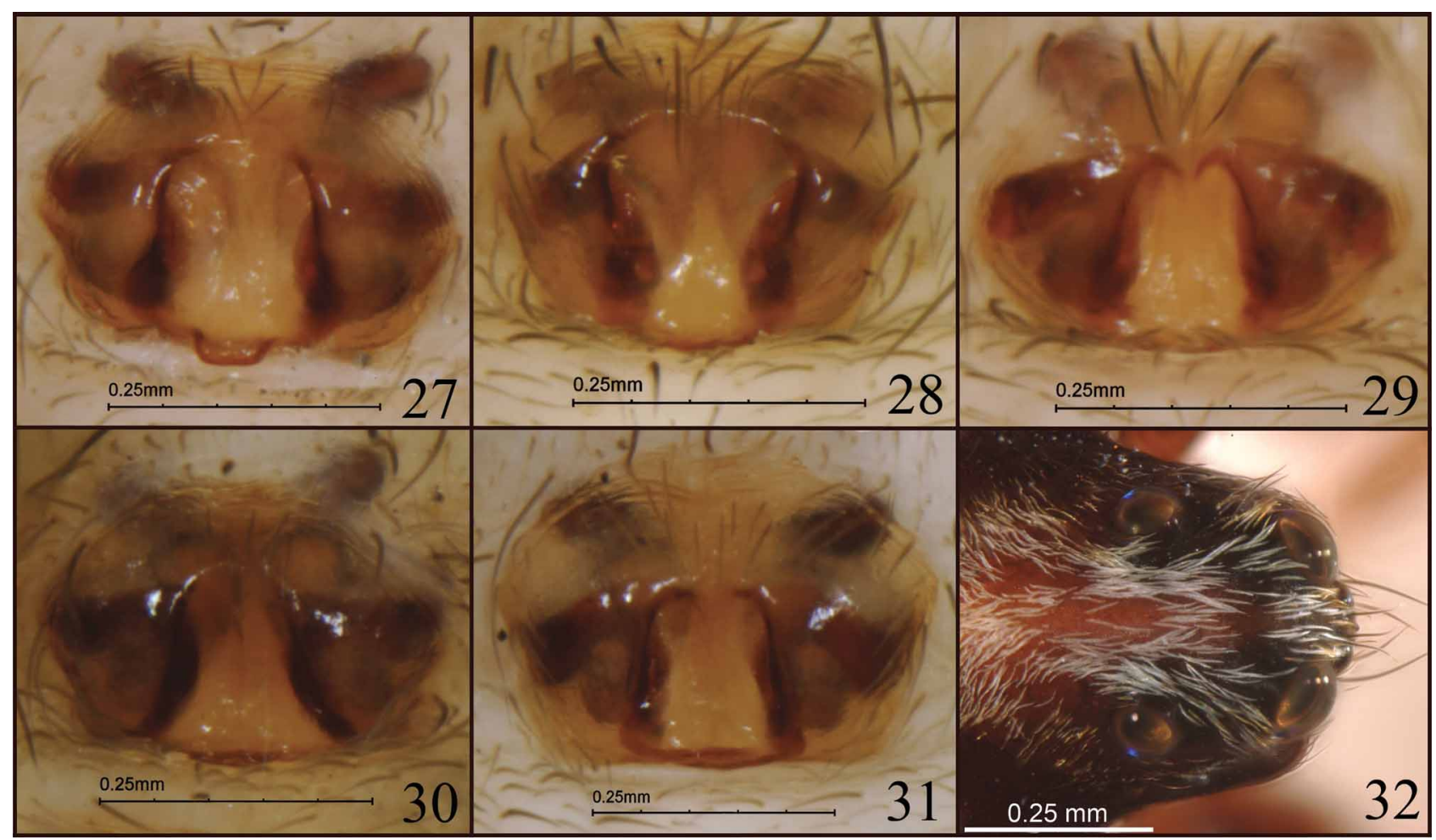

FIGURES 27-32. Lobizon corondaensis (Mello-Leitão), variability. 27-31, epigynes of five specimens collected together in Parque Nacional Chaco (MACN-Ar 13618); 32, male from Suipacha (MACN-Ar 16220), showing the whitish setae on cephalic area.

Synonymy. The types of $P$. corondaensis and A. anomala were compared and show no significant morphological differences.

Distribution. North-Central Argentina (Jujuy, Salta, Chaco, Misiones, Corrientes, Santa Fe, Entre Ríos, Mendoza and Buenos Aires Provinces) (Fig. 83).

Natural history. Most of the specimens recently collected by us in Chaco National Park and also in Corrientes were found sifting leaf litter in forests typical of the Wet Chaco biome. We also collected many specimens with the same method in the lower parts of Calilegua National Park. In the Yungas of the higher parts of Calilegua this species is replaced by L. ojangureni sp. nov. (see below). Rubio et al. (2008) reported that in the Mburucuyá National Park, Corrientes, this species (as Trochosippa anomala) is more abundant in the hygrophilous woodlands than in the neighboring grasslands.

\section{Lobizon minor (Mello-Leitão, 1941) comb. nov.}

(Figs 45-48, 84)

Alopecosa minor Mello-Leitão 1941: 122, fig. 18; female holotype from Argentina: La Rioja Bajo de Doria, Chilecito, in MLP number 14671, examined.

Trochosippa minor-- Roewer 1955: 303.

Other material examined. ARGENTINA: Salta: XI.1939, no collector, no precise locality, 1 female (MACN-Ar 16306); X.1965 collector illegible, 1 female (MACN-Ar 16304). Tucumán: Tafí del Valle, ca. 265' 52 'S, 65²' 'W,11.I.1985, Szumik C. \& Goloboff P., 1 female (MACN-Ar 16296). Mendoza: Cachenza (Cacheuta?), ca. 3257'S, 6849’W,X.1965, Maury E., 1 female (MACN-Ar 16293). San Luis: Cortaderas, ca. $33^{\circ} 17^{\prime}$ S, $66^{\circ} 18^{\prime}$ W, 10.XII.1982, Roig A., 3 females (MACN-Ar 16295). Formosa: Guaymala, Riacho Pilagá, ca. $26^{\circ} 01^{\prime} S, 58^{\circ} 43^{\prime} \mathrm{W}$, IX.1948, no collector, 1 female (MACN-Ar 16323). Chaco: Dpto. Guemes: El 
Pintado, ca. $24^{\circ} 38^{\prime}$ S, $61^{\circ} 27^{\prime} \mathrm{W}, 1 . X .1959$, Bachmann A. (MACN-Ar 5441). Misiones: Parque Nacional Iguazú, ca. $25^{\circ} 51^{\prime} \mathrm{S}, 5^{\circ} 21^{\prime} \mathrm{W}, 8 . X I I .1995$, Ramírez M., 1 female (MACN-Ar 16291). Córdoba: Huerta

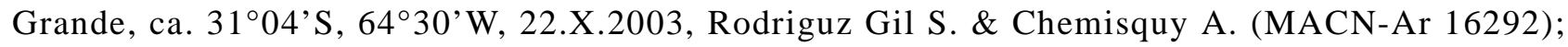
Calamuchita, ca. $31^{\circ} 29^{\prime} \mathrm{S}, 64^{\circ} 13^{\prime} \mathrm{W}$, I.1955, Viana J., 1 female (MACN-Ar 16297). Entre Ríos: Ibicuycito, ca.

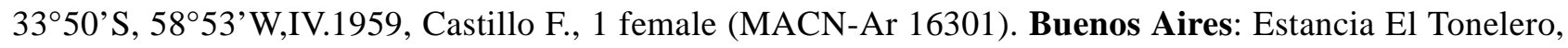
Partido Gral. Lavalle, near canal 2, ca. 36 24'S, 56 58'W, 15-21.XII.1951, Cranwell J., 1 female (MACN-Ar 16298); Otamendi, ca. 34¹3'S, 5854'W, 18.III.1997, Fuentes B., 1 female (MACN-Ar 16299); Mar del

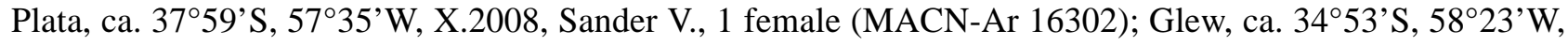
1970, Carpintero (MACN-Ar 16300); Caseros, ca. 34³6'S, 58³3'W, 3.XII.1946, Partridge W., 2 females, 1 immature (MACN-Ar 16303), same locality and collector, 6.XII.1946, 1 female (MACN-Ar 16305).

Diagnosis. Females of $L$. minor are very similar to those of $L$. ojangureni sp. nov. by the shape of the epigyne, with a conspicuous lip projecting ventrally and posteriorly and with rounded furrows on the copulatory openings, but differ by the short copulatory ducts, the usually very large spermathecal heads and by the more rounded and thicker lip margin (Figs 47, 48). Male: Unknown.

Description. Female (MACN-Ar 16292). Dorsal shield of prosoma brown with grey radial pattern, light brown median band narrowing posteriorly and pale submarginal bands. Dorsal shield of prosoma covered with short brown setae, median band with few long black bristles from the fovea to the PLE, four long black bristles on the clypeal condyle anteriorly of AER. Sternum yellow, sparsely covered with brown bristles, more abundant on the margins. Labium dark grey. Chelicerae darker than labium, reddish-brown and covered with brown bristles.

Dorsum of opisthosoma with the same colours and pattern as in L. corondaensis; venter yellow with some dusk patches; spinnerets yellow. Legs brown with dark annulations. Leg formula IV > I > III > II. Spination of leg I, femur: three dorsal, one apico-prolateral; tibia: two ventral pairs, one apico-ventral spine and one prolateral; metatarsus: three ventral pairs, and one apico-ventral spine. Epigyne: with rounded furrows divided by a short longitudinal septum and conspicuous lip projecting ventrally and posteriorly; in dorsal view the heads of spermathecae are large, with a short stalk; the copulatory ducts run ectally to the spermathecae; vulval chambers smaller than the spermathecae.

Male. Unknown.

Measurements. Female, MACN-Ar 16292: TL 5.73. PL 2.93, PW 2.00, PH 1.20, OL 2.80. Eyes: AME 0.10, ALE 0.07, PME 0.29, PLE 0.22. Row of eyes: AM 0.59, PME 0.71, PLE 0.88. Sternum (length/width) 1.30/1.07. Labium (length/width) 0.40/0.33. Legs: length of segments (femur + patella/tibia + metatarsus + tarsus $=$ total length): Pedipalp $0.80+1.00+-+0.97=2.77, \mathbf{I} 1.77+2.37+1.33+0.80=6.27, \mathbf{I I} 1.67+2.10$ $+1.27+0.83=5.87$, III $1.67+2.07+1.47+0.80=6.01$, IV $2.13+2.87+1.22+1.07=7.29$

Variation. Females (range, mean \pm s.d.): TL $4.14-5.96,4.98 \pm 0.53$; PL $2.73-2.93,2.65 \pm 0.22$; PW $1.67-$ $2.13,1.88 \pm 0.14 ; n=9$. The specimens from the dry central areas of Argentina (as the holotype, Fig. 48) have large spermathecal heads, much larger than the vulval chambers, but the specimens from wet areas (Buenos Aires, Misiones and Entre Ríos) have smaller spermathecal heads, almost equal to the vulval chambers. These differences may indicate that there are two species involved, but given the high variability found in other species of the genus, we prefer to postpone their formal recognition until the corresponding males are found.

Distribution. This species shows a wide range and occurs in almost all the North-Central Provinces of Argentina (Salta, La Rioja, Tucumán, Misiones, Formosa, Chaco, Entre Rios, Córdoba, San Luis, Mendoza and Buenos Aires) (Fig. 84).

\section{Lobizon ojangureni sp. nov.}

(Figs 2, 49-58, 86)

Type material. Male holotype (MACN-Ar 18319) and female paratype (MACN-Ar 18318) from Argentina: Jujuy: Parque Nacional Calilegua, near Monolito, 2340'52.3”S, 6454'05.1 W (+/-13 m, WGS84), elev. 1709 
m (GPS), C. Grismado, M. Izquierdo, F. Labarque, G. Rubio, M. Burger, P. Michalik, P. Carrera, A. Ojanguren-Affilastro \& C. Mattoni coll., 06-11.XII.2008; hand collecting.

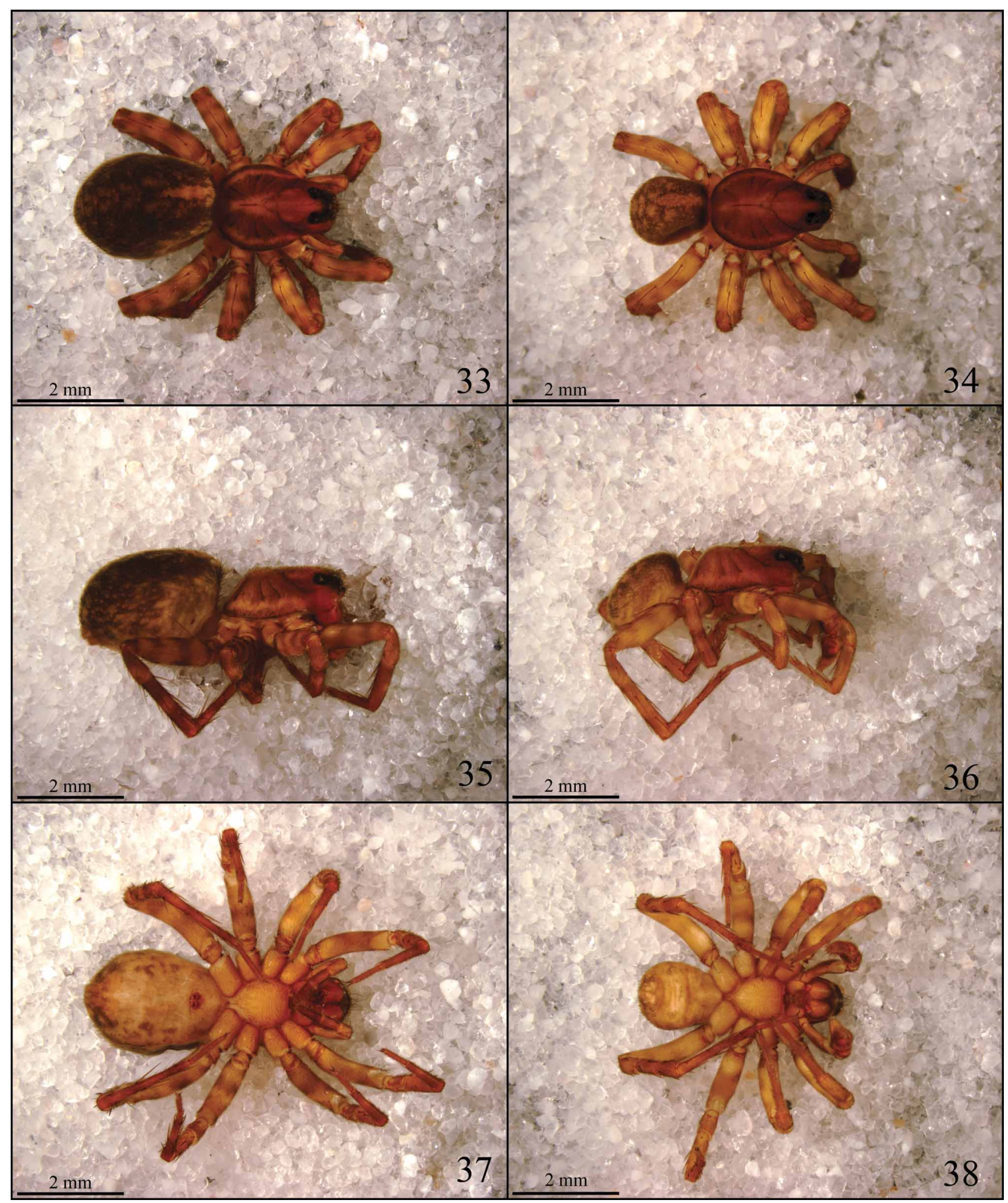

FIGURES 33-38. Lobizon humilis (Mello-Leitão), habitus of preserved specimens from Reserva Natural Otamendi. 33, 35, 37, female (MACN-Ar 16239); 34, 36, 38, male (MACN-Ar 16257); 33-34, dorsal; 35-36, lateral; 37-38, ventral. 



FIGURES 39-44. Genitalia of Lobizon humilis (Mello-Leitão). 39-40, female from Reserva Natural Otamendi (MACN-Ar 16239); 41, male from Don Torcuato (MACN-Ar 16277); 42, female from Las Gamas (MACN-Ar 16275); 43-44, male from Don Torcuato (MACN-Ar 16268); 39, epigyne, ventral; 40, 42, vulvae, cleared, dorsal; 41, dissected embolic division (asterisk: lateral outgrowgth of the embolus) 43, left palp, retrolateral; 44, same, ventral. 
Other material examined. ARGENTINA: Jujuy: same data as the type material, 3 males, 6 females, 6 immatures (MACN-Ar 18321); same data, 1 female (MACN-Ar 18322); same data, 1 female (MACN-Ar 18320); same locality, 1700 m, 9.VIII.1997, Ramírez M. \& Compagnucci L., 1 male (MACN-Ar 16322); same locality, road to Valle Grande, ca. $23^{\circ} 40^{\prime}$ 'S, $64^{\circ} 54^{\prime} \mathrm{W}, 1700 \mathrm{~m}$, XI.1976, Galiano M. E., 1 female (MACN-Ar 16310); Parque Nacional Calilegua: 20,7 km above park entrance, ca. 2339' S, 64 57' W, 23.IX.1995, Ramírez M., Goloboff P. A. \& Szumik C., 2 males (MACN-Ar 16313); same locality and collectors, $19.7 \mathrm{~km}$ above park entrance, 23-24.IX.1995, 2 males (MACN-Ar 16312); same data, 1 male, 2 females (MACN-Ar 16311); same locality, near Sevenguillar, $3 \mathrm{~km}$ above Mesada Las Colmenas, ca. 2344'S, 6451'W, 7.IX.1997, Ramírez M. \& Compagnucci L., 1 male (MACN-Ar 16318); same locality and collectors, 1500 m, 8.VIII.1997, 1 male, 1 immature (MACN-Ar 16314); same data, 2 females, 10 immatures (MACN-Ar 16315); Seccional Aguas Negras, 2345'43.3'S, 6451'04.7'W (+/-10 m., WGS84), 605 m, $06-$ 11.XII.2008, Grismado C., Izquierdo M., Labarque F., Rubio G., Burger M., Michalik P., Carrera P., Ojanguren A. \& Mattoni C., 1 female (MACN-Ar 18323); same data, 1 female (MACN-Ar 18324). Salta: Ojo de Agua, Ruta Nac. 9 km 1640-1642 m., border with Jujuy, ca. 24³1'S, 64²47’W, 22.IX.1995, Ramírez M., Goloboff P. A. \& Szumik C., 1 male (MACN-Ar 16325). Tucumán: Ruta 307, km 36, ca. 2701'S, 65³9’W, 1.XI.2004, Grismado C. \& Compagnucci L. A., 1 female (MACN-Ar 16316); same data, 2 males, 2

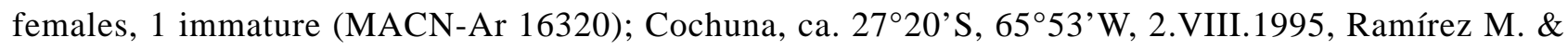
Goloboff P. A., 4 females (MACN-Ar 16321); road between Tucumán and Tafí del Valle, wet forest, ca. $27^{\circ} 00^{\prime} \mathrm{S}, 6^{\circ} 36^{\prime} \mathrm{W}, 1400 \mathrm{~m}, 13 . \mathrm{IX} .1965$, Wegrausch, 3 females (MACN-Ar 16319). Catamarca: Esquina

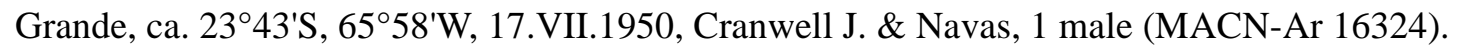
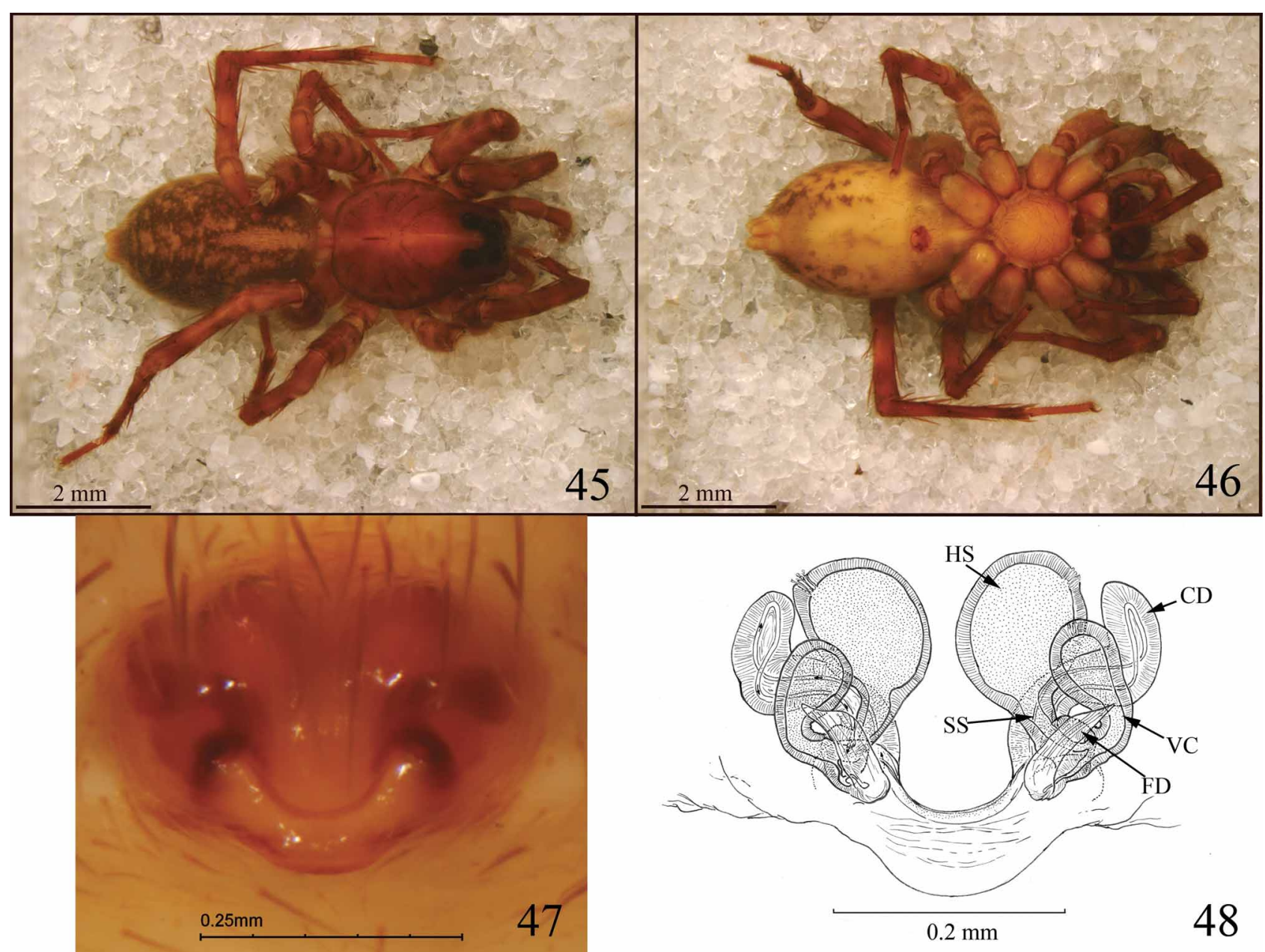

FIGURES 45-48. Lobizon minor (Mello-Leitão), female holotype. 45, habitus dorsal; 46, same, ventral; 47, epigyne, ventral; 48, vulva, cleared, dorsal. 


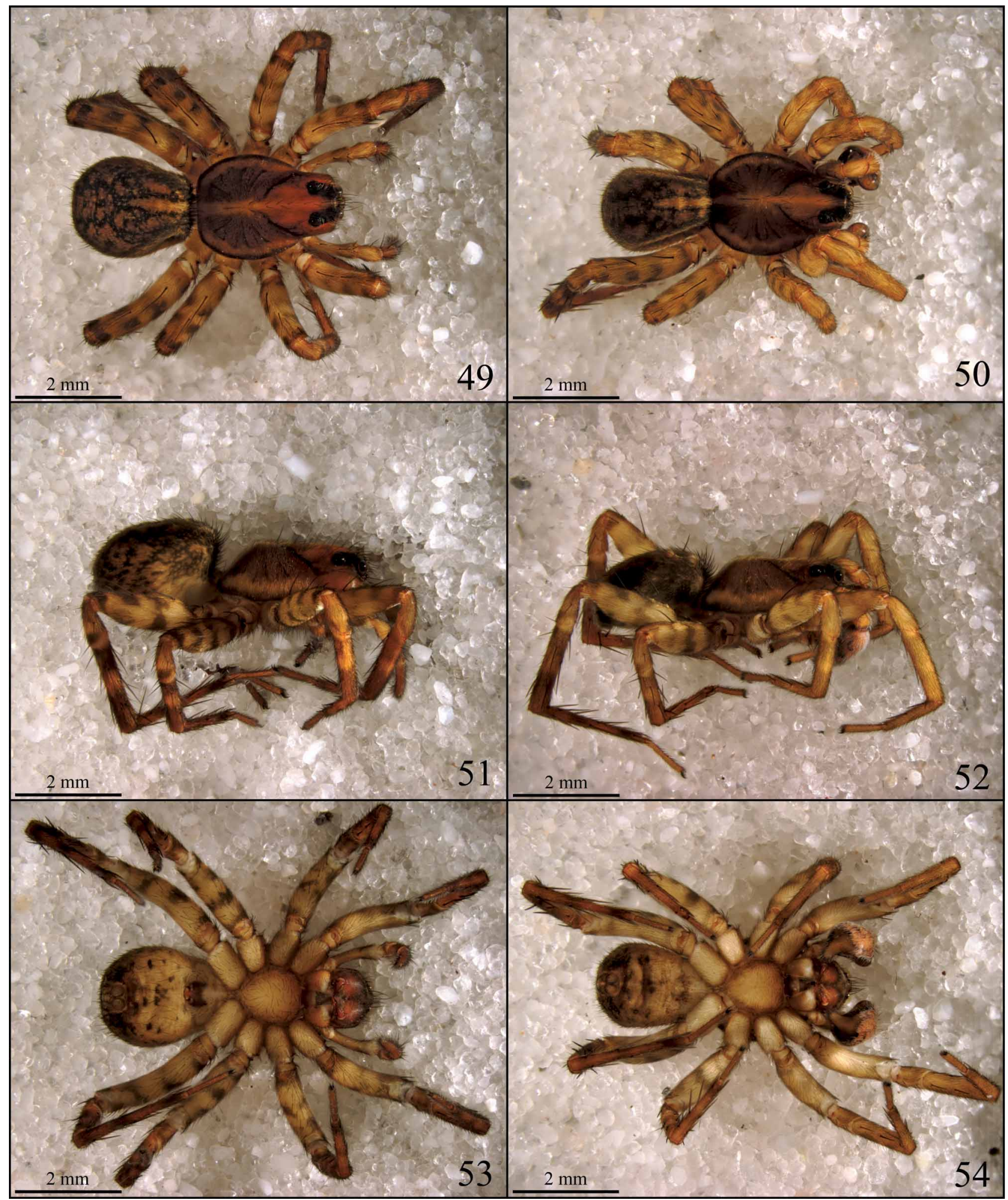

FIGURES 49-54. Lobizon ojangureni sp. nov., habitus of preserved specimens from Parque Nacional Calilegua. 49, 51, 53, female paratype (MACN-Ar 18318); 50, 52, 54, male holotype (MACN-Ar 18319); 49-50, dorsal; 51-52, lateral; 53-54, ventral.

Diagnosis. Females of L. ojangureni sp. nov. are very similar to L. minor in the shape of the epigyne, but the ventral projecting lip has a thinner border and the copulatory ducts are more strongly convoluted (Figs 55, 56). Males resemble those of L. corondaensis in the broad palp with very long embolus and curved tip of the 
terminal apophysis, but L. ojangureni sp. nov. have a more deeply excavated tegulum, exposing a large sector of the bulb in ventral view. The embolus is longer than in L. corondaensis, with a more distal origin (Figs 5758).
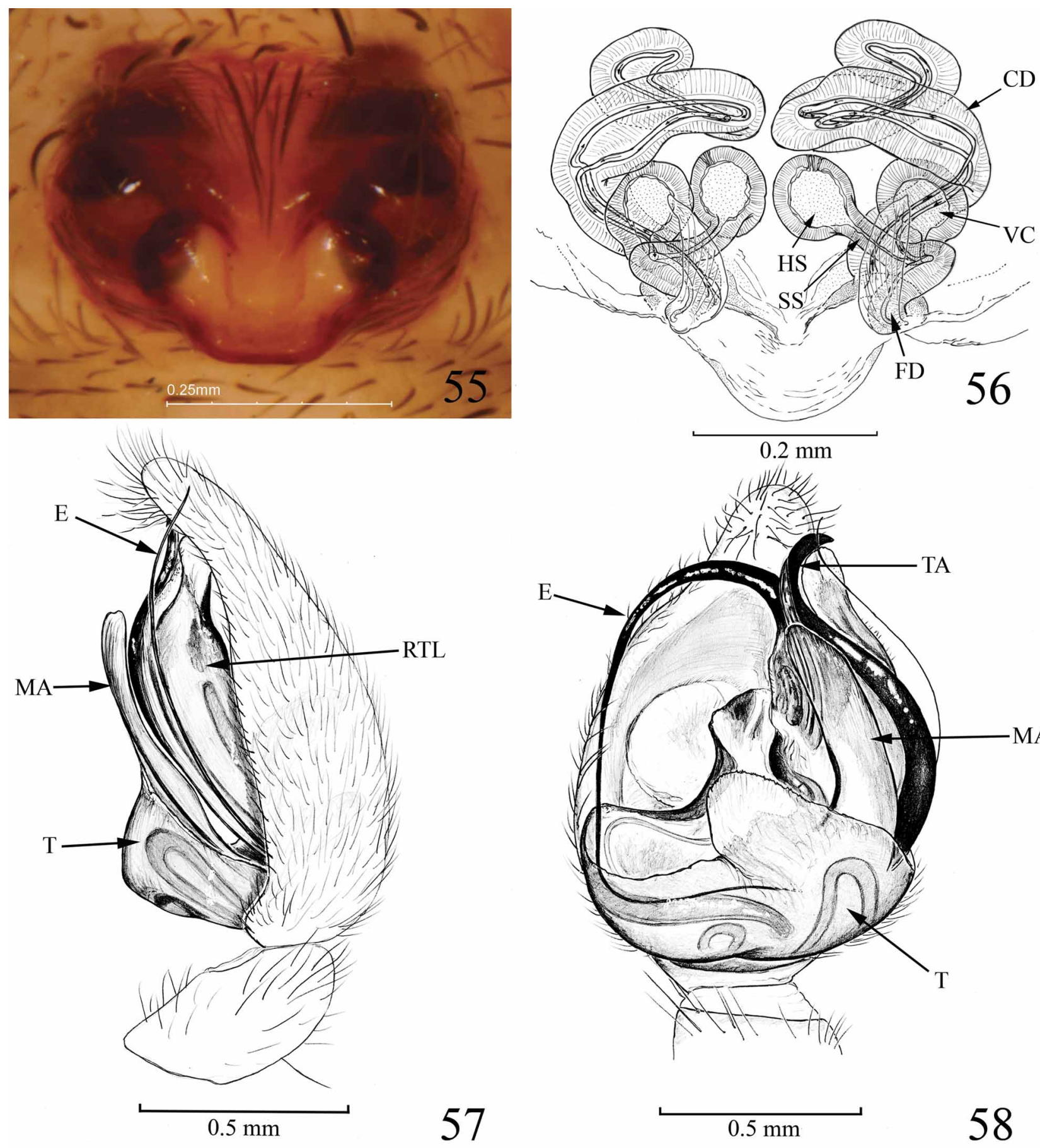

FIGURES 55-58. Lobizon ojangureni sp. nov. 55-56, female from Tucumán, Ruta Prov. 307 (MACN-Ar 16320); 5758, male from Parque Nacional Calilegua (MACN-Ar 16313); 55, epigyne, ventral; 56, vulva, cleared, dorsal; 57, left palp, retrolateral, 58, same, ventral.

Description. Male (holotype). Dorsal shield of prosoma brown with grey radial pattern, light median band narrowing posteriorly and pale submarginal bands. Dorsal shield of prosoma covered with short brown setae; median band with few long black bristles from the fovea to the PLE; four long black bristles on the clypeal condyle anteriorly of AER. Sternum yellow, sparsely covered with brown bristles, more abundant on 
the margins. Labium dark grey. Chelicerae darker than labium, reddish-brown, covered with brown bristles. Opisthosoma dark olive-grey; light yellow lanceolate mark on the cardiac area, followed and flanked by a series of light reddish patches, more abundant in the posterior half. Venter yellow with some dusk patches; spinnerets yellow. Legs brown with dark annulations. Palp with a dense patch of bristles on venter of femur, and white setae on dorsal section of cymbium. Palp with a very long embolus with apical origin, tegulum subdivided, terminal apophysis long with tip curved retro-dorsally, median apophysis laminar and longitudinally oriented. The sperm ducts run ventrally from retrolateral to prolateral, and make a loop in the retroventral side of the tegulum. Leg formula IV > I > II > III. Spination of leg I: femur, three dorsal, one apico-prolateral; tibia, three ventral pairs and one prolateral; metatarsus three ventral pairs and one prolateral spine.

Female (paratype). Colouration and setae arrangement as in male. Spination of leg I: femur, three dorsal, one apico-prolateral; tibia, three ventral pairs, and two prolateral spines; metatarsus, three ventral pairs. Epigyne with a lip projecting ventrally and posteriorly, rounded furrows on the copulatory openings, divided by a central septum; spermathecae and copulatory ducts are visible trough the ventral cuticle. Spermathecae and vulval chambers of similar size, cylindrical stalks and copulatory ducts strongly convoluted (Figs 55-56).

Measurements. Female, paratype (male, holotype): TL 5.16 (4.87), PL 2.83 (2.70), PW 2.00 (2.00), PH 0.93 (0.90), OL 2.33 (2.17). Eyes: AME 0.07 (0.07), ALE 0.07 (0.07), PME 0.28 (0.28), PLE 0.21 (0.21). Row of eyes: AM 0.50 (0.50), PME 0.67 (0.69), PLE 0.86 (0.86). Sternum (length/width) 1.30/1.07 (1.23/ 1.07). Labium (length/width) 0.39/0.40 (0.34/0.36). Legs: length of segments (femur + patella/tibia + metatarsus + tarsus $=$ total length): Pedipalp $1.00+0.93+-+0.77=2.70, \mathbf{I} 1.80+2.30+1.30+0.73=6.13$, II $1.67+2.13+1.30+0.77=5.87$, III $1.67+1.80+1.50+0.77=5.74$, IV $2.17+3.80+2.33+0.97=9.27$ (pedipalp $1.00+0.93+-+1.20=3.13, \mathbf{I} 1.80+2.37+1.40+0.77=6.34$, II $1.67+2.13+1.40+0.77=5.97$, III $1.57+1.87+1.47+0.77=5.68$, IV $2.13+2.60+2.37+0.97=8.07)$.

Variation. Females (males) (range, mean \pm s.d.): TL 4.47 - 5.93, 5.01 \pm 0.42 ; CL $2.40-2.83,2.64 \pm 0.17$; CW $1.67-2.10,1.90 \pm 0.16 ; \mathrm{n}=10 ;$ (TL $4.40-5.24,4.71 \pm 0.28$; CL 2.37 - 2.70, 2.58 0.11; CW 1.77 - 2.97, $2.18 \pm 0.51 ; \mathrm{n}=10$ ).

Etymology. The specific epithet is a patronymic in honor of the arachnologist Andrés A. OjangurenAffilastro in recognition of his help in collecting this species in the Parque Nacional Calilegua, and also for his assistance and companionship during many other productive trips in Argentina.

Natural History. This species was collected at the type locality and in Tucumán by hand or sifting leaf litter in the Yungas. Some females were collected with eggsacs in December.

Distribution. Montane forest (Yungas) in northwestern Argentina (Jujuy, Salta, Tucumán and Catamarca) (Fig. 86).

Lobizon humilis (Mello-Leitão, 1944) comb.nov.

(Figs 6-8, 11-12, 33-38, 79, 81, 85)

Alopecosa humilis Mello-Leitão 1944: 338-339 (fig. 28); male holotype from Argentina, Buenos Aires, Tigre, Guayracá, Prosen coll. in MLP 16015, examined.

Alopecosa unguiculata Mello-Leitão 1944: 339-341 (fig. 29); female holotype from Argentina, Buenos Aires, Tigre, Guayracá, Prosen coll., deposited in MLP number 16020, examined. New synonymy.

Other material examined. ARGENTINA: Corrientes: Parque Nacional Mburucuyá, $27^{\circ} 58^{\prime}-26^{\circ} 05^{\prime \prime}$, 57 $59^{\prime}-58^{\circ} 08^{\prime} \mathrm{W}$, specimens examined by Rubio et al. (2008, under Alopecosa), 1 male, 9 female. Santa Fe: Las Gamas, 20 km W Vera, ca. 29²5'S, 60²1'W, 27.X.1994, Ramírez M. \& Faivovich J., 1 female, 1 immature (MACN-Ar 16275); same data, 1 male (MACN-Ar 16278); same locality, 25.III.1995, Ramírez M. Goloboff P. Szumik C. \& Faivovich J., 1 female (MACN-Ar 16264). San Luis: Merlo, ca. 3209'S, 6531'W, XI.1970, 1 female (MACN-Ar 16265). Córdoba: Cura Brochero, ca. 31²3'S, 64²11'W, IV.1994, Ramírez M., 
1 female, 5 immatures (MACN-Ar 16263); Calamuchita, ca. $31^{\circ} 29^{\prime} \mathrm{S}, 64^{\circ} 13^{\prime} \mathrm{W}$, I.1955, Viana J. M., 1 female (MACN-Ar 16274). Buenos Aires: Otamendi, ca. 3413'S, 5854'W, 25.IV.1998, Fuentes B., 1 female (MACN-Ar 16251); same locality and collector, 27.XII.1997, 1 female (MACN-Ar 16253); same locality and collector, 18.X.1997, 1 female (MACN-Ar 16258); same locality and collector, 1 female (MACN-Ar 16252); same locality and collector, 3 males (MACN-Ar 16250); same locality and collector, 4 females (MACN-Ar 16254); same locality and collector, 25.X.1997, 2 females (MACN-Ar 16256); same locality and collector, 9.I.1998, 3 females (MACN-Ar 16255); same locality and collector, 27.XII.1997, 1 female (MACN-Ar 16259); same locality and collector, 14.XII.1997, 3 females (MACN-Ar 16260); same locality and collector, 2 males (MACN-Ar 16257); Reserva Natural Otamendi, ca. 34²13'S, 58 54' W, pitfall traps, 25.X.1997, Fuentes B. \& di Iorio O., 4 females (MACN-Ar 16240); same locality and collector, 28 males (MACN-Ar 16246); same locality and collector, 21.II.1998, 5 females (MACN-Ar 16239); same locality and collector, 15.XI.1997, 23 males (MACN-Ar 16237); same locality and collector, 18.X.1997, 4 females (MACN-Ar 16241); same locality and collector, 14 males (MACN-Ar 16247); same locality and collector, 1 male (MACN-Ar 16245); same locality and collector, 24.I.1998, 7 females (MACN-Ar 16243); same locality and collector, 1 male (MACN-Ar 16242); same locality and collector, 9.I.1998, 2 females (MACN-Ar 16248); same locality and collector, 1 male (MACN-Ar 16244); same locality and collector, 15.XI.1997, 1 female (MACN-Ar 16249); same locality and collector, 15.II.1998, 2 males (MACN-Ar 16238); Reserva Natural Otamendi, Est. Río Luján, 34²16'45.1"S, 5853'15.1 W, 4m., 25-7.III-IV.2007, Grismado C., Damer L., López N., Olejnik N., Crudele I., 1 female, 1 immature (MACN-Ar 12342); same locality, 19.V.2007, C. Grismado, S. Trivero, N. Olejnik \& I. Crudele, 1 male (MACN-Ar 12514); same locality, 30.VI.2007, C. Grismado, L. Damer, N. López, S. Trivero \& N. Olejnik, 1 male, 22 immature (MACN-Ar 12662); same locality, 30-28.VI-VII.2007, Grismado C., Damer L., Crudele I., Olejnik N., Trivero S., López N., de Biase S., 1 female (MACN-Ar 12827); Atucha, ca. 3358'S, 59¹7’W, 15.IX.1999, Ramírez M., 1 female, 4 immatures (MACN-Ar 16266); same locality, 27.VIII.1991, Ramírez M., 1 female (MACN-Ar 16261); Bella Vista, ca. $34^{\circ} 35^{\prime}$ S, 58 $42^{\prime}$ W, IV.2003, Piacentini L., 2 males, 3 females (MACN-Ar 16262); General Madariaga, ca. $37^{\circ} 00^{\prime}$ S, $57^{\circ} 08^{\prime} \mathrm{W}$, XII.1952, De Carlo and D'Amico, 1 male, 7 female (MACN-Ar 3743); Isla Martín García, ca. $34^{\circ} 09^{\prime} \mathrm{S}, 58^{\circ} 15^{\prime} \mathrm{W}, 1940$, Viana J. M., 1 male, 1 female, 2 immatures (MACN-Ar 16273); San Fernando, ca. $34^{\circ} 26^{\prime}$ S, $58^{\circ} 33^{\prime}$ W, XII.2002, Piacentini L., 1 female, 1 immature (MACN-Ar 16236); same locality, 1 female (MACN-Ar 16269); Don Torcuato, ca. 34³0'S, 58³9'W, X.2002, Piacentini L., 1 male, 1 female (MACN-Ar 16268); same locality, 1 female (MACN-Ar 16267); same locality, VIII.2002, Piacentini L., 2 males, 2 females (MACN-Ar 16271); same locality, I.2002 Piacentini L., 2 males, 1 female (MACN-Ar 16277); Sierra de los Padres, ca. 3756'S, 57²6'W, XI.1962, Galiano M. E., 2 females (MACNAr 16279); Tigre, 2.XI.1951, Viana J. M., 4 females (MACN-Ar 16272); same locality and collector, 17.VII.1951, 2 males, 1 females, 2 immatures (MACN-Ar 16270); same locality and collector, 2.X.1950, 1 female (MACN-Ar 3052).

Diagnosis. Males of L. humilis differ from L. corondaensis and L. ojangureni by a narrower palp with a shorter embolus, and by the shorter median apophysis that barely surpasses the ventral part of the tegulum; the median apophysis converges with the terminal apophysis, which has a pointed, not strongly curved tip (Figs 6-8, 43-44). The male palp resembles those of $L$. otamendi sp. nov., but $L$. humilis have a less conspicuously peaked projection on the retrolateral tegular lobe, and a less curved profile of the cymbium (Figs 43-44). Lobizon humilis is larger and lacks the contrasting pattern on the opisthosoma (Figs 33-38). Females resemble those of L. minor and L. ojangureni sp. nov. in their rounded copulatory openings with elevated borders, but the median field is straight, not projecting in a lip (Figs 11, 39); the copulatory ducts have a different trajectory (Figs 12, 40,42), passing usually between the spermathecal heads, not diverging laterally as in $L$. minor and L. ojangureni sp. nov.

Description. Male (MACN-AR 16257). Dorsal shield of prosoma brown with grey radial pattern, light brown median band narrowing posteriorly and pale submarginal bands. Dorsal shield of prosoma median band with few long black bristles from the fovea to the PLE; four long black bristles on the clypeal condyle anteriorly of AER. Sternum yellow, sparsely covered with brown bristles, more abundant on the margins. 
Labium dark grey. Chelicerae darker than labium, reddish-brown, covered with brown bristles. Colour and pattern of the opisthosoma in dorsal view as in L. corondaensis; venter yellow with some dusk patches; spinnerets yellow. Legs brown with dark annulations. Leg formula IV > I > III > II; spination of leg I: femur, three dorsal, one apico-prolateral; tibia, three ventral pairs, and one prolateral; metatarsus, three ventral pairs and two prolateral spines (one in the centre, one apical). Palp with a dense retrolateral patch of bristles on the femur. Bulb with short embolus of prolateral apical origin, tegulum subdivided, the retrolateral tegular lobe have a conspicuous peaked projection (Figs 8, 43-44), terminal apophysis long with the terminal part slightly curved retro-dorsally, median apophysis small and laminar, longitudinal. The basal embolic lateral outgrowth is folded, seemingly a roll (Figs 6-8, 41, 43). The sperm ducts run ventrally from the retrolateral to prolateral, and make a loop in the middle of the ventral side of the tegulum.

Female (MACN-Ar 16239).

Colouration and setae arrangement as in male. Leg formula IV > I > III > II; spination of leg I: femur, three dorsal, one apico-prolateral; tibia, three ventral pairs, one prolateral; metatarsus, three ventral pairs. Epigyne with rounded copulatory openings with elevated borders, the posterior margin is straight (Figs 11, 39); copulatory ducts passing between the spermathecal heads. Dictynoid pore conspicuous, located on common base of vulval chambers and stalk of the spermathecae (Fig. 12).

Measuraments. Female, MACN-Ar 16239 (male, MACN-AR 16257): TL 5.16 (4.87), PL 2.83 (2.70), PW 2.00 (2.00), PH 0.93 (0.90), OL 2.33 (2.17). Eyes: AME 0.07 (0.07), ALE 0.07 (0.07), PME 0.28 (0.28), PLE 0.21 (0.21). Row of eyes: AM 0.50 (0.50), PME 0.67 (0.69), PLE 0.86 (0.86). Sternum (length/width) 1.30/1.07 (1.23/1.07). Labium (length/width) 0.39/0.40 (0.34/0.36). Legs: length of segments (femur + patella/tibia + metatarsus + tarsus $=$ total length $):$ Pedipalp $1.00+0.93+-+0.77=2.70, \mathbf{I} 1.80+2.30+1.30$ $+0.73=6.13$, II $1.67+2.13+1.30+0.77=5.87$, III $1.67+1.80+1.50+0.77=5.74$, IV $2.17+3.80+2.33$ $+0.97=9.27$ (Pedipalp $1.00+0.93+-+0.70=1.80, \mathbf{I} 1.80+2.37+1.40+0.77=6.34, \mathbf{I I} 1.67+2.13+1.40$ $+0.77=5.97$, III $1.57+1.87+1.47+0.77=5.68$, IV $2.13+2.60+2.37+0.97=8.07$ ).

Variation. Females (males) (range, mean \pm s.d.): TL 3.17 - 5.24, 4.27 \pm 0.70 ; CL $1.73-2.50,2.20 \pm 0.28$;

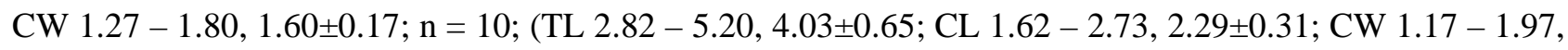
$1.60 \pm 0.23 ; \mathrm{n}=10$ ). The female specimens from Santa Fe and Córdoba are considerably smaller, have shorter copulatory ducts and relatively smaller vulval chambers (as in Fig. 42), but their epigynes are almost identical to those from Buenos Aires Province. The male from Santa Fe is also comparatively small, but the palp is identical to those of the typical specimens.

Synonymy. The type of A. unguiculata was compared with large samples of females of A. humilis and we found no significant morphological differences.

Distribution. Central and central-eastern Argentina (San Luis, Córdoba, Santa Fe, Corrientes and Buenos Aires Province) (Fig. 85).

Natural history.The data from the Mburucuyá National Park, Corrientes (Rubio et al. 2008) suggests that, unlike L. corondaensis, this species prefers open grasslands. In the Reserva Natural Otamendi, where the largest series was collected, most spiders were found beating the bases of grasses in a halophilous grassland near Río Luján, and by pitfall traps in the "chilcal" (Baccharis sp.), although several specimens were also caught by the same method in the "talar" (forest of Celtis tala). The specimens from Atucha were collected with Berlese funnels (data from the label), and the specimens from Don Torcuato (Buenos Aires metropolitan area) were caught under moist vegetation in suburban gardens.

\section{Lobizon otamendi sp. nov.}

(Figs 59-68, 86 )

Type material. Male holotype (MACN-Ar 16309) and female paratype (MACN-Ar 16307) from Argentina: Buenos Aires Province, Department of Campana, Reserva Natural Otamendi, ca. $34^{\circ} 13^{\prime} \mathrm{S}, 58^{\circ} 54^{\prime} \mathrm{W}$, pitfall in dense "chilcal" (Baccharis sp.), 9.I.1998, B. Fuentes \& O. Di Iorio coll. 


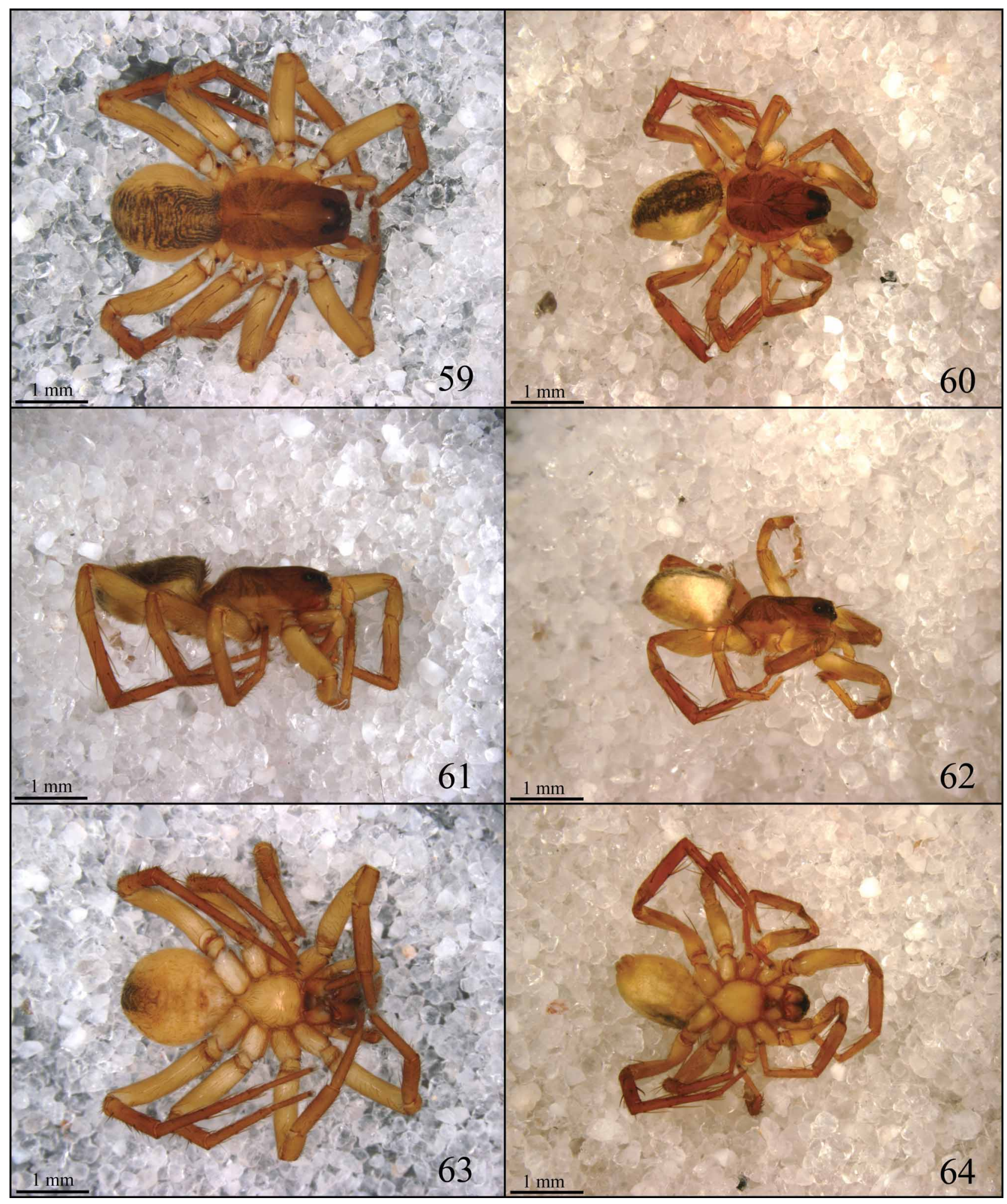

FIGURES 59-64. Lobizon otamendi sp. nov., habitus of preserved specimens from Reserva Natural Otamendi. 59, 61, 63, female paratype (MACN-Ar 16307); 60, 62, 64, male holotype (MACN-Ar 16309); 59-60, dorsal; 61-62, lateral; 63-64, ventral.

Other material examined. ARGENTINA: Buenos Aires: Reserva Natural Otamendi, Estación Río Luján, halophilous grassland of "pelo de chancho" (Distichlis sp.), pitfall trap, 34¹6’43.4"S, 5853”16.2"W, alt. 6m, 3-17.XI.2007, Grismado C., Damer L., López N., Trivero S. \& Grismado A., 1 female (MACN-Ar 12123); Caseros, ca. 34³6’S, 58³3'W, 6.XII.1946, Partridge W. 1 female (MACN-Ar 16308). 

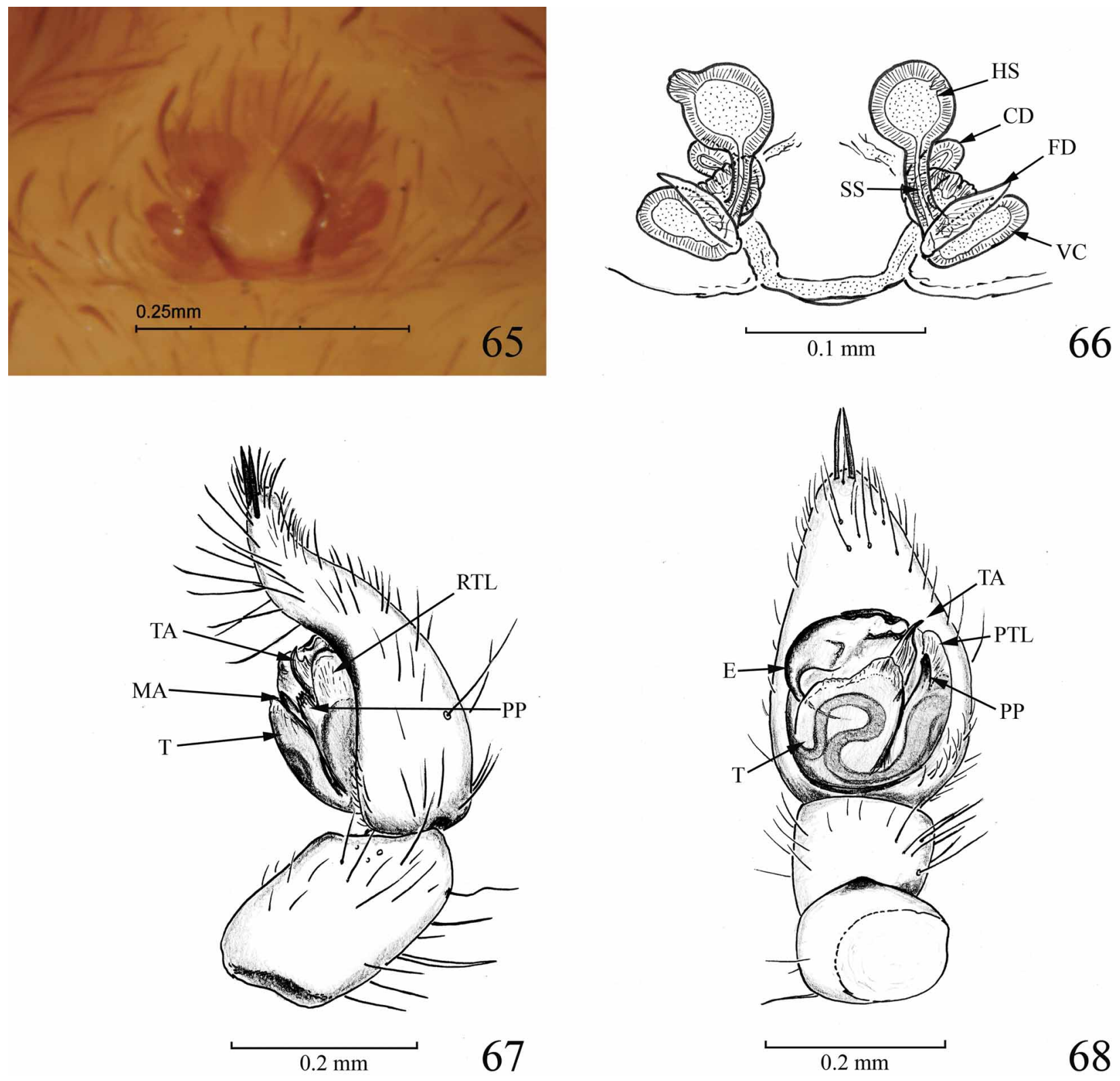

68

FIGURES 65-68. Lobizon otamendi sp. nov. 65, female paratype (MACN-Ar 16307), epigyne, ventral; 66, female from Caseros (MACN-Ar 16308), vulva, cleared, dorsal; 67-68, male holotype (MACN-Ar 16309); 67, left palp, retrolateral, 68 , same, ventral.

Diagnosis. Lobizon otamendi sp. nov. is in the morphology of the male genitalia very similar to $L$. humilis, but differs by the larger peaked protrusion on the retrolateral tegular lobe and by the curved profile of the cymbium in retrolateral view (Figs 67-68). The retrolateral patch of setae on the palpal femur is much less dense than in the other Lobizon species. The epigyne is similar to that of L. corondaensis in the shape of the polygonal median field, but the copulatory ducts are shorter, the base of spermathecae is larger and the vulval chambers are elongated, laterally directed (Figs 65-66). This species is the smallest in the genus, and shows a contrasting dichromatic pattern on the opisthosoma (grey dorsally, pale yellowish ventrally) and proportionately reduced eyes (Figs 59-64).

Description. Male (holotype). Dorsal shield of prosoma brown with grey radial pattern, broad pale brown marginal bands. Dorsal shield of prosoma covered with short brown setae, median band with few long black bristles from the fovea to the PLE; four long black bristles on the clypeal condyle in front to AER. Sternum yellow; sparsely covered with brown bristles, more abundant on the margins. Labium dark grey. Chelicerae 
darker than labium, reddish-brown; covered with brown bristles. Dorsum of opisthosoma with dark olive-grey central band with sparse light patches; sides and venter yellow; spinnerets yellow. Leg femora yellow, all other segments brown, without annulations. Leg formula IV > I > III > II. Spination of leg I: femur, three dorsal, one apico-prolateral, three ventral pairs, two prolaterals (one in the middle, the other apical); metatarsus, three ventral pairs. Palp with a patch of sparse bristles on venter of femur, cymbium with two strong macrosetae. Cymbium with sinuous outline in lateral view; short embolus of apico-prolateral origin; tegulum subdivided, the retrolateral tegular lobe has a very conspicuous peaked projection (Figs 67-68); terminal apophysis short with the terminal part slightly curved retrodorsally; median apophysis small and laminar, oriented longitudinally. The sperm duct runs ventrally from retrolateral to prolateral, and makes a loop in the retroventral side of the tegulum.

Female (paratype). Colouration and setae arrangement as in male. Leg formula IV > I > III > II. Spination of leg I: femur, three dorsal, one apico-prolateral; tibia, two ventral pairs; metatarsus, three ventral pairs. Epigyne with a polygonal median field, short copulatory ducts; base of spermathecae large, vulval chambers elongated, directed laterally (Figs 65-66).

Measurements. Female, paratype (male, holotype): TL 3.97 (2.87), PL 1.90 (1.47), PW 1.33 (2.07), PH 0.63 (0.43), OL 2.07 (1.40). Eyes: AME 0.08 (0.06), ALE 0.06 (0.04), PME 0.12 (0.11), PLE 0.09 (0.07). Row of eyes: AM 0.39 (0.28), PME 0.38 (0.30), PLE 0.50 (0.40). Sternum (length/width) 0.97/0.77 (0.80/ 0.63). Labium (length/width) 0.22/0.29 (0.18/0.21). Legs: length of segments (femur + patella/tibia + metatarsus + tarsus $=$ total length): Pedipalp $0.63+0.43+-+0.47=1.53, \mathbf{I} 1.27+1.67+0.97+0.53=4.44$, II $1.30+1.50+1.00+0.57=4.37$, III $1.27+1.50+1.03+0.50=4.30$, IV $1.70+2.20+1.77+0.83=6.50$ (Pedipalp $0.47+0.23+-+0.40=1.10, \mathbf{I} 0.97+1.33+0.80+0.57=3.67, \mathbf{I I} 0.97+1.20+0.63+0.50=$ 3.30 , III $0.90+1.17+0.83+0.43=3.33$, IV $1.17+1.60+1.30+0.63=4.70$.

Variation. Females (males) (range, mean \pm s.d.): TL 1.63 - 3.97, 3.72 \pm 0.36 ; CL $1.83-1.90,1.87 \pm 0.05$; CW $1.33-1.37,1.35 \pm 0.03 ; n=2$ (TL $2.87-3.43,3.15 \pm 0.40$; CL $1.47-1.83,1.65 \pm 0.25$; CW $1.07-1.50$, $1.29 \pm 0.31 ; n=2)$.

Etymology. The specific epithet is a noun in apposition referring to the type locality.

Natural history. The specimens from the type locality were caught in pitfall traps in grassland and in "chilcal" of Baccharis sp. (Asteraceae).

Distribution. Only known from two localities in northeastern Buenos Aires: the Reserva Natural Otamendi and Caseros (Buenos Aires metropolitan area) (Fig. 86).

\section{Navira gen. nov.}

Type species. Navira naguan sp. nov.

Etymology. The generic name means "cacique" (tribal leader) in the language of the Henîa people (northern Comechingones), a native extinct aboriginal ethnic group from central Argentina. Gender feminine.

Diagnosis. Navira gen. nov. is clearly distinguished from Lobizon gen. nov. by its glabrous integuments and the unusual transverse banded abdominal pattern, similar among wolf spiders only to the Australian lycosine Mainosa (Framenau 2006c). Both characters are here considered apomophies. The palp conformation is very similar to Lobizon gen. nov., but lacks the retrolateral patch of setae on the femur (Fig. 80), the bulb is reduced in relation to the whole palp; the embolus, the median apophysis and the retrolateral tegular lobe are shorter than in Lobizon gen. nov. species (Figs 77-78). Navira gen. nov. can be further distinguished from Lobizon gen. nov. by having three teeth on the cheliceral retromargin (Fig. 82), and by the simpler female genitalia, in which the vulval chambers are inconspicuous (an additional potential apomorphy) and the copulatory ducts are very short (Figs 13-14, 75-76).

Description. Small wolf spider (TL 4.40-5.93). Females larger than males. 


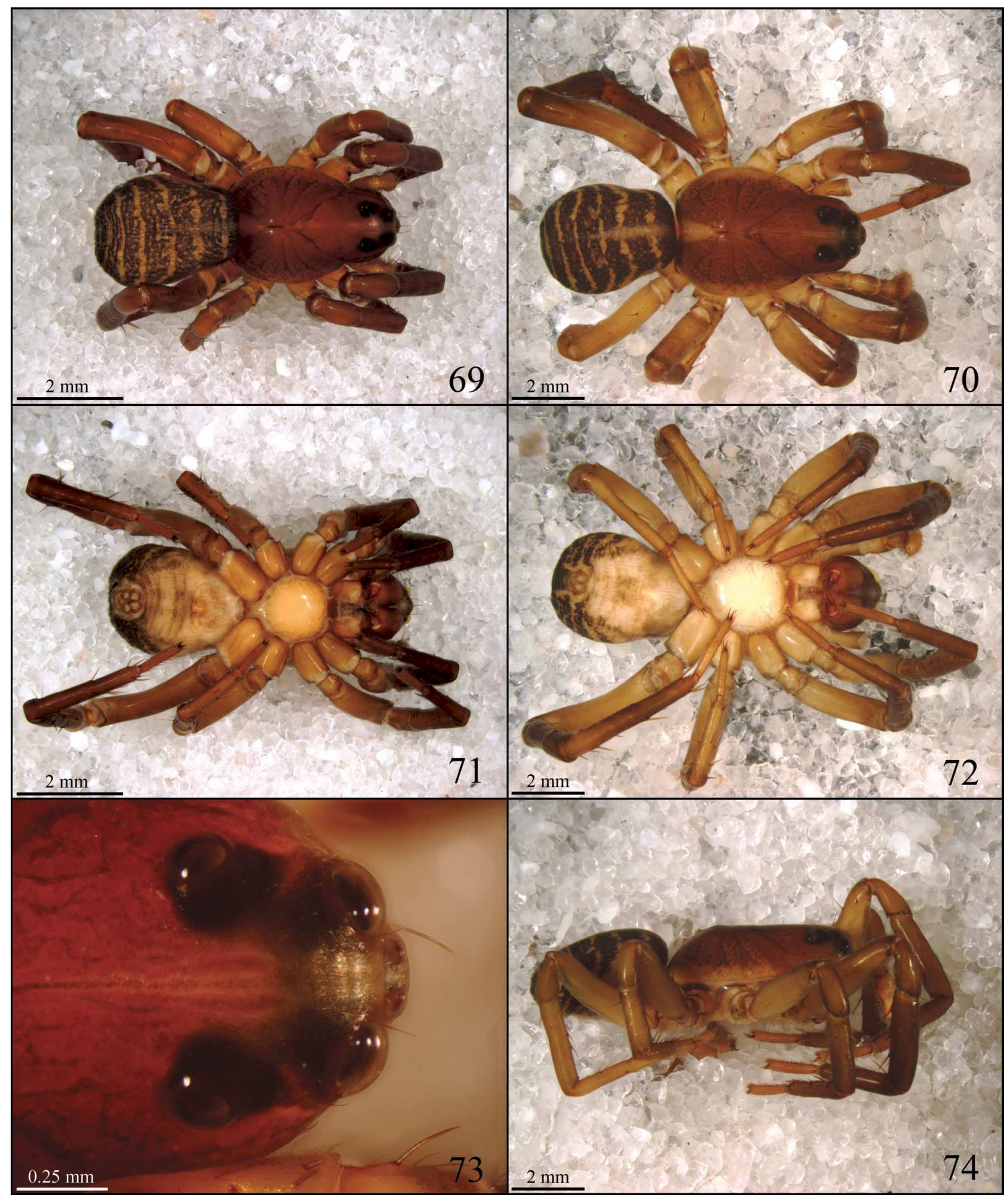

FIGURES 69-74. Navira naguan sp. nov., habitus of preserved specimens from Merlo. 69, 71, female paratype (MACN-Ar 16280); 70, 72-74, male holotype (MACN-Ar 16281); 69-70, dorsal; 71-72, ventral; 74, lateral; 73, detail of the ocular area and the clypeal condyle.

Dorsal shield of prosoma brown, with dark grey radial pattern and light brown marginal bands. Eyes surrounded by black area. Dorsal shield of prosoma without bristles; with four long bristles on the extremely protuding clypeal condyle, anteriorly of AER (Fig. 73). Three promarginal teeth, the median largest; three retromarginal teeth, similar in size. Opisthosoma dark with a light yellow lanceolate mark on the cardiac area 
and a pattern of pale transverse bands (Fig. 70). Carapace longer than wide, dorsal line straight in lateral view (Fig. 74). Caput flanks in frontal view steep in males, but a gentle slope in females. Leg formula IV $>$ I $>$ III > II. Spination of leg I: femur, two dorsal; tibia, four ventral pairs, metatarsus with three ventral pairs, and one apico-dorsal.
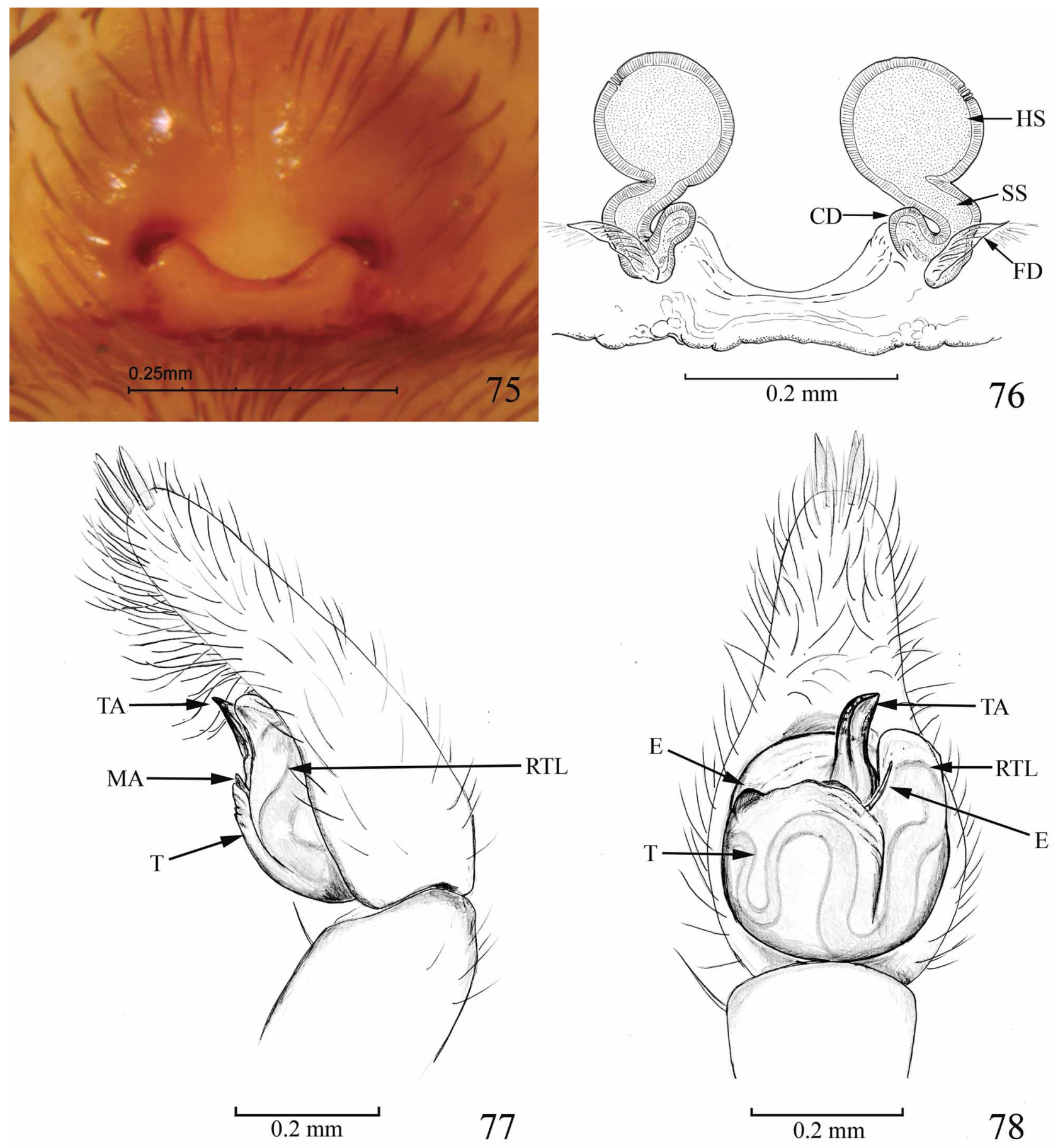

FIGURES 75-78. Navira naguan sp. nov. 75, female paratype, epigyne, ventral (MACN-Ar 16280); 76, female paratype Merlo (MACN-Ar 16280), vulva, cleared, dorsal; 77-78, male holotype (MACN-Ar 16281); 77, left palp, retrolateral, 78, same, ventral.

Femur of palp without patch of bristles (Fig. 80), tegulum divided, embolus short, the median apophysis is laminar and reaches the apical border of the tegulum; the terminal apophysis is long, with a curved apical part. 
The epigyne is a simple plate with a transverse septum, with the copulatory opening on the lateral borders of the septum; the vulval chambers are inconspicuous and the copulatory ducts are very short.

Composition. Only the type species, $N$. naguan sp. nov.

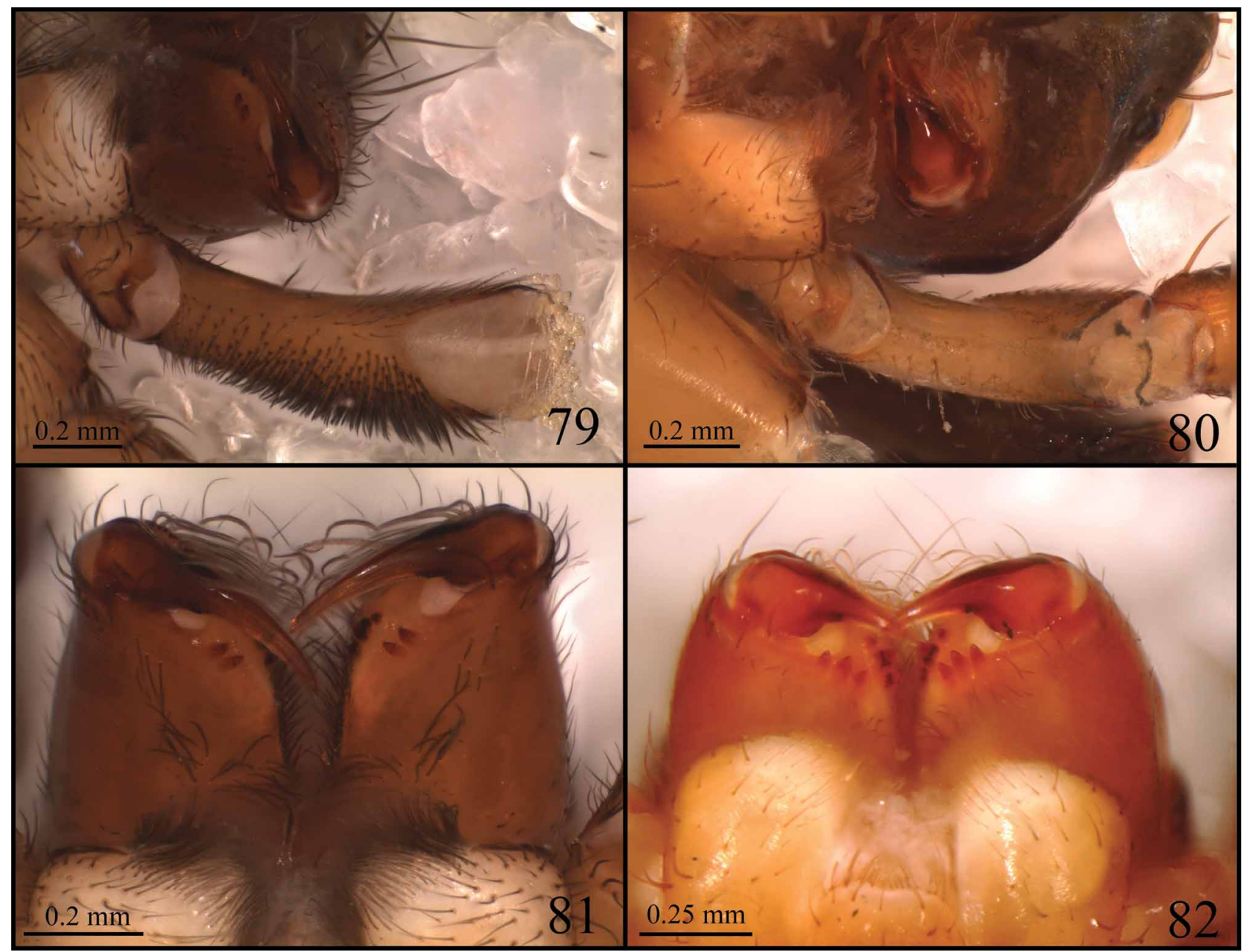

FIGURES 79-82. 79, 81, Lobizon humilis (Mello-Leitão) male from Reserva Natural Otamendi (MACN-Ar 12514), 80, 82, Navira naguan sp. nov., 80, male without locality (MACN-Ar 16286), 82, female without locality (MACN-Ar 16283). 79, 80, left palpal femur, ventral view. 81, 82, cheliceral retromargin, posterior view.

\section{Navira naguan sp. nov.}

(Figs 13-14, 69-78, 80, 82, 86)

Type material. Male holotype from Argentina, San Luis Province, Merlo, ca. 3209'S, 65³1'W, 22.XI.1983, M. E. Galiano coll. (MACN-Ar 16281), and two female paratypes from the same locality, 12.XI.1982, A. Roig coll. (MACN-Ar 16280).

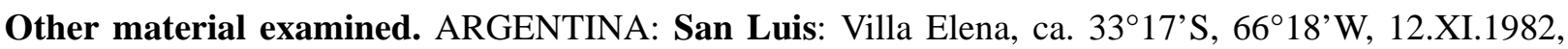
Maury E., 2 females (MACN-Ar 16285). Córdoba: Agua de Oro, ca. 31²6'S, 640'' W, 1940, De Carlo J. A., 1 female (MACN-Ar 1088); Bosque Alegre, ca. 31 ${ }^{\circ} 28^{\prime} \mathrm{S}, 6^{\circ} 12^{\prime} \mathrm{W}, 20 \mathrm{~km}$ Carlos Paz, I.1981, Grosso, Zanetic A. \& Goloboff P.A., 4 females (MACN-Ar 16282); Copina, ca. 31³4'S, 644'W, XII.1983, Ferradás B. R., 2 females (MACN-Ar 16289); Calamuchita, ca. $31^{\circ} 29^{\prime} \mathrm{S}, 6^{\circ} 13^{\prime} \mathrm{W}$, I.1945, Viana M., 1 female (MACN-Ar 4932); $17 \mathrm{~km} \mathrm{~W}$ Villa Icho Cruz, ca. $31^{\circ} 28^{\prime} \mathrm{S}, 6^{\circ} 32^{\prime} \mathrm{W}, 6 . I I .1981$, Roig A., 1 female (MACN-Ar 16287). WITHOUT LOCALITY: 3.I.1946, illegible collector, 1 male (MACN-Ar 16290); 1 female (MACN-Ar 16283); 09.X.1964, illegible collector, 1 male (MACN-Ar 16286).

Diagnosis. As per genus. 


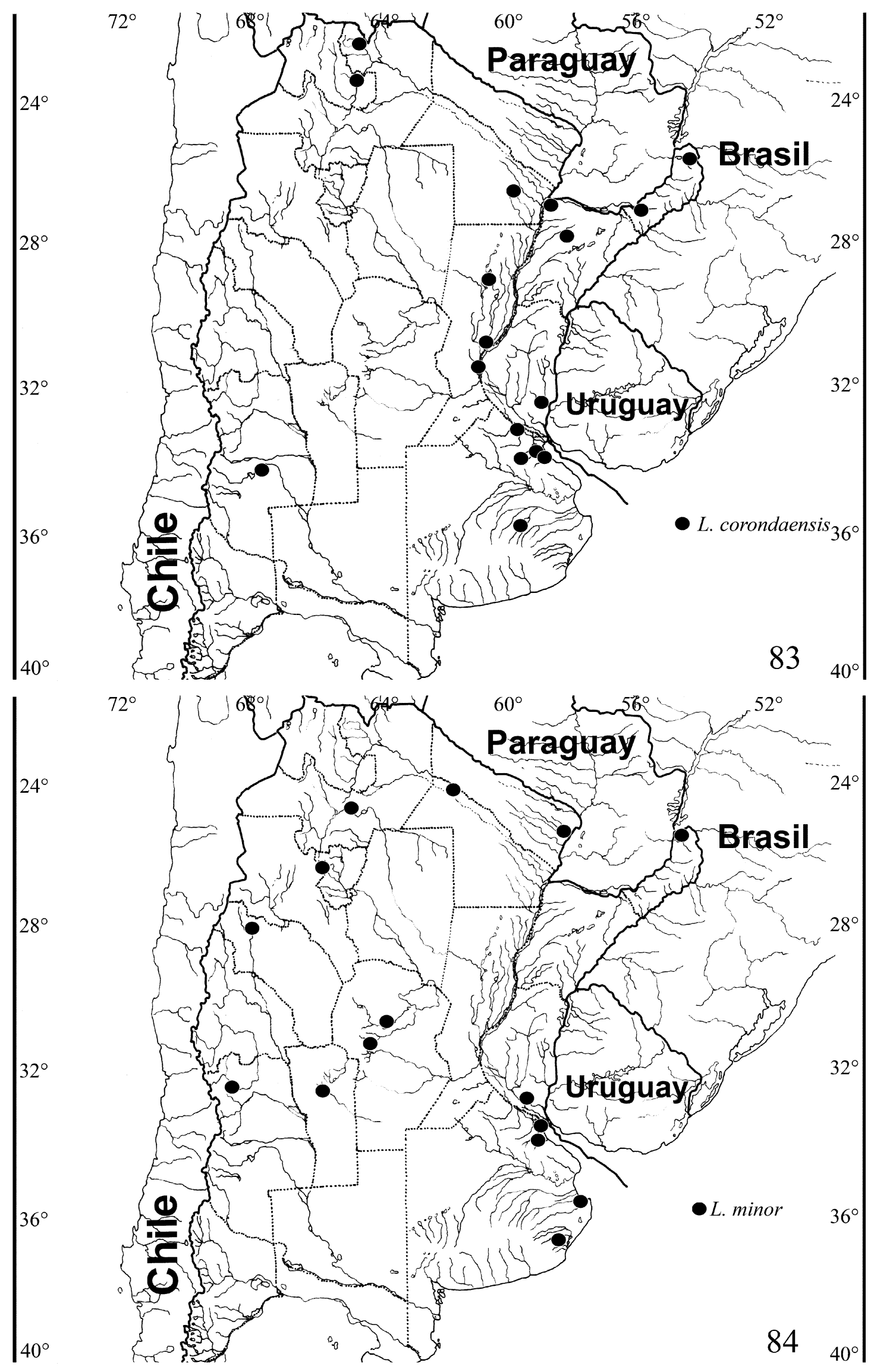

FIGURES 83, 84. Geographic distribution of Lobizon gen. nov. 83, Lobizon corondaensis (Mello-Leitão), 84, Lobizon minor (Mello-Leitão). 


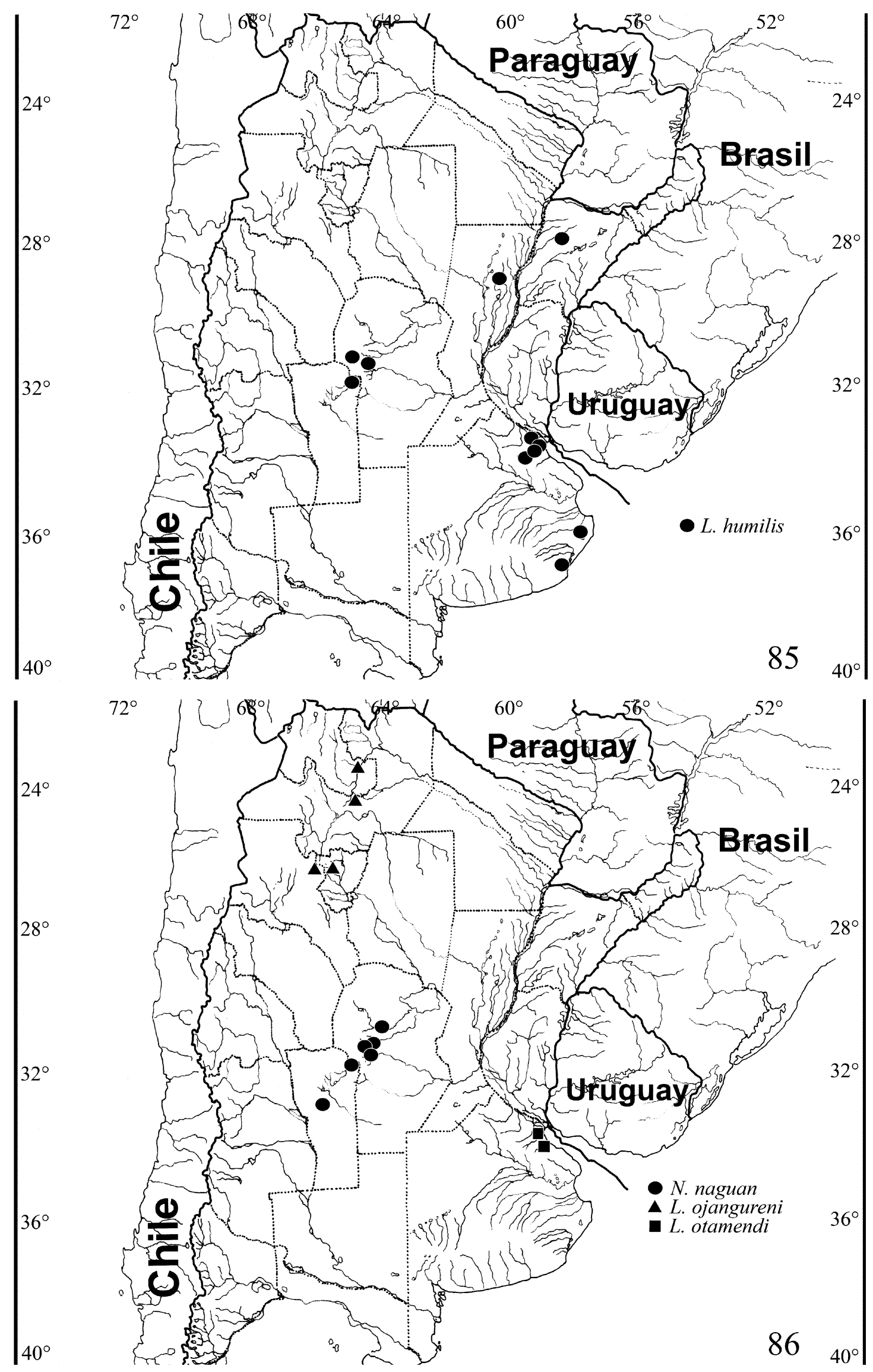

FIGURES 85, 86. Geographic distribution of Navira gen. nov. and Lobizon gen. nov. 85, Lobizon humilis (MelloLeitão), 86, Lobizon ojangureni sp. nov. (triangles), L. otamendi sp. nov. (squares) and Navira naguan gen. nov. sp. nov. (circles). 
Description. Male (holotype). Dorsal shield of prosoma brown, as in genus description. Sternum yellow; with a few black bristles. Labium dark grey. Chelicerae darker than labium, reddish-brown, covered with brown bristles; three promarginal teeth, the median largest; three retromarginal teeth, similar in size. Opisthosoma with the typical pattern of the genus in dorsal view; venter yellow (Fig. 72).

Colouration of legs: femur yellow in apically, remaining articles of the leg brown without annulations. Leg formula IV > I > III > II. Spination of leg I: femur, two dorsal; tibia, four ventral pairs, metatarsus with three ventral pairs, and one apico-dorsal. Palp as for genus.

Female (paratype). Colouration and setae as in male. Leg formula IV > I > III > II; spination of leg I: femur, two dorsal and one prolateral apical spines; tibia, four ventral pairs; metatarsus, three ventral pairs, and one apico-dorsal. Genitalia as for genus.

Measurements. Female, paratype (male, holotype): TL 5.16 (4.87), PL 2.83 (2.70), PW 2.00 (2.00), PH 0.93 (0.90), OL 2.33 (2.17). Eyes: AME 0.07 (0.07), ALE 0.07 (0.07), PME $0.28(0.28)$, PLE $0.21(0.21)$. Row of eyes: AM 0.50 (0.50), PME 0.67 (0.69), PLE 0.86 (0.86). Sternum (length/width) 1.30/1.07 (1.23/ 1.07). Labium (length/width) $0.39 / 0.40$ (0.34/0.360). Legs: length of segments (femur + patella/tibia + metatarsus + tarsus $=$ total length): Pedipalp $1.00+0.93+-+0.77=2.70, \mathbf{I} 1.80+2.30+1.30+0.73=6.13$, II $1.67+2.13+1.30+0.77=5.87$, III $1.67+1.80+1.50+0.77=5.74$, IV $2.17+3.80+2.33+0.97=9.27$ (pedipalp $1.00+0.93+-+0.73=2.13, \mathbf{I} 1.80+2.37+1.40+0.77=6.34$, II $1.67+2.13+1.40+0.77=5.97$, III $1.57+1.87+1.47+0.77=5.68$, IV $2.13+2.60+2.37+0.97=8.07)$.

Variation. Female (male) (range, mean \pm s.d.): TL $4.47-5.93,5.01 \pm 0.42$; CL $2.40-2.83,2.64 \pm 0.17$; CW $1.67-2.10,1.90 \pm 0.16 ; n=10$ (TL $4.40-5.24,4.71 \pm 0.28$; CL $2.37-2.70,2.58 \pm 0.11$; CW $1.77-2.97$, $2.18 \pm 0.51 ; n=10)$.

Etymology. The specific epithet is a noun in aposition taken from the word "naguan", also meaning "cacique" (tribal leader) but in the language of the Kamiare people (southern Comechingones).

Distribution. Argentina, Córdoba and San Luis Provinces (Fig. 86).

Natural history. Unknown.

\section{Acknowledgments}

We thank to Luis Pereira, Cristina Damborenea and Mónica Tassara (Museo de La Plata) for loaning the relevant type specimens under their care; to Martín Ramírez, Matías Izquierdo (MACN), Cor Vink (Biosecurity Group, New Zealand), Estevam Luís Cruz da Silva (PUCRS) and, especially to the editor Volker Framenau for their critical comments on the manuscript; to Eder Soares Álvares (Instituto Butantan) for useful discussions at the beginning of this project; to the Administración de Parques Nacionales of Argentina and the Dirección de Recursos Naturales, Subdirección de Fauna y Flora de la Provincia de Corrientes for authorizations to work in protected areas; to the personnel of the National Parks Chaco, Calilegua, Iguazú, Reserva Natural Otamendi, and the Estación Biológica de Corrientes (EBCo), and all our co-collectors for their assistance in the field work; to Matías Izquierdo and Facundo Labarque (MACN) for help with the SEM images. Support for this study were provided by Museo Argertino de Ciencias Naturales and grants FONCyT PICT-2007-01393 and CONICET PIP 112-200801-03209 to Martín Ramírez.

\section{References}

Aisenberg, A. \& Costa, F.G. (2005) Females without sperm transfer maintain high sexual receptivity in the spider Schizocosa malitiosa (Araneae, Lycosidae). Ethology, 111, 454-558.

Aisenberg, A., Estramil, N., González, M., Toscano-Gadea, C.A. \& Costa, F.G. (2008) Silk release by copulating Schizocosa malitiosa males (Araneae, Lycosidae): a bridal veil? Journal of Arachnology, 36, 204-206.

Alderweireldt, M. (1991) A revision of the African representatives of the wolf spider genus Evippa Simon, 1882 (Araneae, Lycosidae) with notes on allied species and genera. Journal of Natural History, 25, 359-382. 
Alderweireldt, M. (1996) A taxonomic revision of the genus Ocyale Audouin, 1826 in Africa (Araneae: Lycosidae). Journal of Natural History, 30, 1349-1365.

Alderweireldt, M. (1999) A revision of central African Trabea (Araneae, Lycosidae) with the description of two new species from Malawi and a redescription of T. purcelli. Journal of Arachnology, 27, 449-457.

Alderweireldt, M. \& Jocqué, R. (1993) A redescription of Tricassa deserticola Simon, 1910, representing the Tricassinae, a new subfamily of wolf spiders (Araneae, Lycosidae). Belgian Journal of Zoology, 123, 27-38.

Alderweireldt, M. \& Jocqué, R. (2005) A taxonomic review of the Afrotropical representatives of the genus Hippasa (Araneae, Lycosidae). Journal of Afrotropical Zoology, 2, 45-68.

Álvares, S.S. (2006) A subfamília Lycosinae no Brasil (Araneae, Lycosidae), com notas sobre espécies ocorrentes em países limítrofes. Ph.D. thesis, Instituto de Biociências, Universidade de São Paulo, São Paulo, 237 pp.

Brady, A.R. (1980) Nearctic species of the wolf spider genus Trochosa (Araneae: Lycosidae). Psyche, 86, $167-212$.

Brady, A.R. \& McKinley, K.S. (1994) Nearctic species of the wolf spider genus Rabidosa (Araneae: Lycosidae). Journal of Arachnology, 22, 138-160.

Capocasale, R.M. (1991) New contributions to the genus Porrimosa Roewer (Araneae, Lycosidae). Journal of Arachnology, 19, 93-96.

Capocasale, R.M. (2001a) Redescripción de Lycosa poliostoma (C. L. Koch) (Araneae, Lycosidae). Revista Ibérica de Aracnologia, 3, 79-86.

Capocasale, R.M. (2001b) Review of the South American species of the genera Aulonia and Allocosa (Araneae, Lycosidae). Journal of Arachnology, 29, 270-272.

Casanueva, M.E. (1980) Los licosidos de Chile. Estudio biológico y taxonómico por los métodos de sistemática alfa y taxonómia numérica (Araneae: Lycosidae). Gayana Zoologia, 42, 1-76.

Coddington, J.A. (1990) Ontogeny and homology in the male palpus of orb weaving spiders and their relatives, with comments on phylogeny (Araneoclada: Araneoidea, Deinopoidea). Smithsonian Contributions to Zoology, 496, 152

Costa, F.G. (1975) El comportamiento precopulatorio de Lycosa malitiosa Tullgren (Araneae, Lycosidae). Revista Brasileira de Biologia, 35, 359-368.

Costa, F.G. (1979) Análisis de la cópula y de la actividad postcopulatoria de Lycosa malitiosa (Tullgren) (Araneae, Lycosidae). Revista Brasileira de Biologia, 39, 361-376.

Dahl, F. (1908) Die Lycosiden oder Wolfsspinnen Deutschlands und ihre Stellung im Haushalt der Natur. Nach statistischen Untersuchungen dargestellt. Nova Acta Academia Caesareae Leopoldino-Carolinae Germaniae Naturae Curiosum, 88, 175-678.

di Caporiacco, L. (1939) Arachnida. In: Missione biologica nel paese dei Borana. III. Raccolte zoologiche. Parte Seconda. Reale Accademia d'Italia, Centro studi per l'Africa orientale italiana, Roma, pp. 303-385.

Dondale, C.D. (1986) The subfamilies of wolf spiders (Araneae: Lycosidae). Actas X Congreso Internacional de Aracnología, Jaca, España, 1, 327-332.

Dondale, C.D. (2005) Lycosidae. In: Ubick, D., Paquin, P., Cushing, P. E. \& Roth, V. (Eds), Spiders of North America: an Identification Manual. American Arachnological Society, pp. 164-170.

Dondale, C.D. \& Redner, J.H. (1978) Revision of the Nearctic wolf spider genus Schizocosa (Araneida: Lycosidae). Canadian Entomologist, 110, 143-181.

Dondale, C.D. \& Redner, J.H. (1979) Revision of the wolf spider genus Alopecosa Simon in North America (Araneae: Lycosidae). Canadian Entomologist, 111, 1033-1055.

Dondale, C.D. \& Redner, J.H. (1981) Classification of two North American species of Pirata, with a description of a new genus (Araneae, Lycosidae). Bulletin of the American Museum of natural History, 170, 106-110.

Dondale, C.D. \& Redner, J.H. (1983a) Revision of the wolf spiders of the genus Arctosa C. L. Koch in North and Central America (Araneae: Lycosidae). Journal of Arachnology, 11, 1-30.

Dondale, C.D. \& Redner, J.H. (1983b) The wolf spider genus Allocosa in North and Central America (Araneae: Lycosidae). Canadian Entomologist, 115, 933-964.

Framenau, V.W. (2002) Review of the wolf spider genus Artoria Thorell (Araneae: Lycosidae). Invertebrate Systematics, $16,209-235$.

Framenau, V.W. (2005) The wolf spider genus Artoria Thorell in Australia: new synonymies and generic transfers (Araneae, Lycosidae). Records of the Western Australian Museum, 22, 265-292.

Framenau, V.W. (2006a) Knoelle, a new monotypic wolf spider genus from Australia (Araneae: Lycosidae). Zootaxa, $1281,55-67$.

Framenau, V.W. (2006b) Mainosa, a new genus for the Australian "schuttlecock wolf spider" (Araneae: Lycosidae). Journal of Arachnology, 34, 206-213.

Framenau, V.W. (2006c) Revision of the Australian wolf spider genus Anomalosa Roewer, 1960 (Araneae: Lycosidae). Zootaxa, 1304, 1-20.

Framenau, V.W. (2006d) Revision of the wolf spider genus Diahogna Roewer, 1960 (Araneae, Lycosidae). Journal of Natural History, 40, 273-292. 
Framenau, V.W. (2006e) The wolf spider genus Venatrix Roewer: new species, synonymies and generic transfers (Araneae, Lycosidae). Records of the Western Australian Museum, 23, 145-166.

Framenau, V.W. (2007) Revision of the new Australian genus Artoriopsis in a new subfamily of wolf spiders, Artoriinae (Araneae: Lycosidae). Zootaxa, 1391, 1-34.

Framenau, V.W. \& Vink, C.J. (2001) Revision of the wolf spider genus Venatrix Roewer (Araneae: Lycosidae). Invertebrate Systematics, 15, 927-970.

Framenau, V.W., Gotch, T.B. \& Austin, A.D. (2006) The wolf spiders of artesian springs in arid south Australia, with a revalidation of Tetralycosa (Araneae, Lycosidae). Journal of Arachnology, 34, 1-36.

Framenau, V.W. \& Baehr, B.C. (2007) Revision of the Australian wolf spider genus Dingosa Roewer, 1955 (Araneae, Lycosidae). Journal of Natural History, 41, 1603-1629.

Heimer, S. \& Nentwig, W. (1991) Spinnen Mitteleuropas. Ein Bestimmungsbuch. Paul Parey, Berlin and Hamburg, 1$543 \mathrm{pp}$.

Koch, C.L. (1847a) Die Arachniden. Getreu nach der Natur abgebildet und beschrieben. Vierzehnter Band. J. L. Lotzbeck, Nürnberg, pp. 89-210.

Koch, C.L. (1847b) Die Arachniden. Getreu nach der Natur abgebildet und beschrieben. Fünfzehnter Band. J. L. Lotzbeck, Nürnberg, 136 pp.

Koch, L. (1877) Die Arachniden Australiens nach der Natur beschrieben und abgebildet. 1. Theil. 7. Lieferung. Bauer und Raspe, Nrnberg, pp. 889-968.

Koch, L. (1878) Die Arachniden Australiens nach der Natur beschrieben und abgebildet. 1. Theil. 8. Lieferung. Bauer und Raspe, Nrnberg, pp. 969-1044.

Kronestedt, T. (1975) Studies on species of Holarctic Pardosa groups (Araneae, Lycosidae). 1. Redescriptions of Pardosa albomaculata Emerton and descriptions of two new species from North America with comments on some taxonomic characters. Zoologica Scripta, 4, 217-228.

Kronestedt, T. (1981) Studies on species of Holarctic Pardosa groups (Araneae, Lycosidae). 2. Redescriptions of Pardosa modica (Blackwall), Pardosa labradorensis (Thorell), and Pardosa sinistra (Thorell). Bulletin of the American Museum of Natural History, 170, 111-124.

Kronestedt, T. (1986) Studies on species of Holarctic Pardosa groups (Araneae, Lycosidae). 3. Redescriptions of Pardosa algens (Kulczynski), P. septentrionalis (Westring), and P. sodalis Holm. Entomologica Scandinavica, 17, 215-234.

Kronestedt, T. (1987) Studies on species of Holarctic Pardosa groups (Araneae, Lycosidae). 4. redescription of Pardosa tetonensis Gertsch and descriptions of two new species from the western United States. Entomologica Scandinavica, 18, 409-424.

Kronestedt, T. (1993) Studies on species of Holarctic Pardosa groups (Araneae, Lycosidae). 5. Redescription of Pardosa wasatchensis Gertsch and description of a new species from Utah. Journal of Arachnology, 21, 175-183.

Latreille, P.A. (1804) Tableau mthodique des insectes. Nouveau Dictionnaire d'Histoire Naturelle, Paris, 24, 129-295.

Lehtinen, P.T. \& Hippa, H. (1979) Spiders of the Oriental-Australian region. 1. Lycosidae: Venoniinae and Zoicinae. Annales Zoologici Fennici, 16, 1-22.

Lessert, R.d. (1926) Araignées du Kilimandjaro et du Merou (suite et fin). 6. Lycosidae. Revue Suisse de Zoologie, 33, 335-357.

Mello-Leitão, C.F., de (1941) Las Arañas de Córdoba, la Rioja, Catamarca, Tucumán, Salta y Jujuy colectadas por los Profesores Birabén. Revista del Museo de La Plata, Nueva Serie (Sección Zoología), 2, 99-198.

Mello-Leitão, C.F., de (1944) Arañas de la provincia de Buenos Aires. Revista del Museo de La Plata, Nueva Serie (Sección Zoología), 3, 311-393.

Mello-Leitao, C.F., de (1945) Arañas des Misiones, Corrientes y Entre Rios. Revista del Museo de La Plata, Nueva Serie (Sección Zoología), 4, 213-302.

Murphy, N.P., Framenau, V.W., Donnellan, S.C., Harvey, M.S., Park, Y.-C. \& Austin, A.D. (2006) Phylogenetic reconstruction of wolf spiders (Araneae: Lycosidae) using sequences from the 12S rRNA, 28S rRNA, and NADH1 genes: Implications for classification, biogeography, and the evolution of web building behaviour. Molecular Phylogenetics and Evolution, 38, 583-602.

Platnick, N.I. (2009) The World Spider Catalog, Version 9.5. American Museum of Natural History. Avaiable from: http:/ /research.amnh.org/entomology/spiders/catalog/index.html (accessed April 2009).

Roewer, C.F. (1951) Neue Namen einiger Araneen-Arten. Abhandlungen des Naturwissenschaftlichen Vereins zu Bremen, 32, 437-456.

Roewer, C.F. (1955) Katalog der Araneae von 1758 bis 1940, Vol. 2a. Institut Royal des Sciences Naturelles de Belgique, Bruxelles, 923 pp.

Roewer, C.F. (1959) Araneae Lycosaeformia II (Lycosidae). Exploration du Parc National de l'Upemba - Mission GF de Witte, 55, 3-518.

Roewer, C.F. (1960) Araneae Lycosaeformia II (Lycosidae) (Fortsetzung und Schluss). Exploration du Parc National de l'Upemba - Mission GF de Witte, 55, 519-1040. 
Rubio, G.D., Minoli, I. \& Piacentini, L.N. (2008) Patrones de abundancia de cinco especies de arañas lobo (Araneae: Lycosidae) en dos ambientes del Parque Nacional Mburucuyá, Corrientes, Argentina. Brenesia, 67, 59-67.

Russell-Smith, A. (1982) A revision of the genus Trabaea Simon (Araneae: Lycosidae). Zoological Journal of the Linnean Society, 74, 69-91.

Santos, A.D. \& Brescovit, A.D. (2001) A revision of the South American spider genus Aglaoctenus Tullgren, 1905 (Araneae, Lycosidae, Sosippinae). Andrias, 15, 75-90.

Sierwald, P. (1989) Morphology and ontogeny of female copulatory organs in American Pisauridae, with special reference to homologous features (Arachnida, Araneae). Smithsonian Contribution to Zoology, 484, 1-24.

Sierwald, P. (2000) Description of the male of Sosippus placidus, with notes on the subfamily Sosippinae (Araneae, Lycosidae). Journal of Arachnology, 28, 133-140.

Simon, E. (1876) Les arachnides de France, Tome 3. Librairie encyclopédique de Roret, Paris,: pp. 1-364.

Simon, E. (1885) Etudes sur les Arachnides recueillis en Tunisie en 1883 et 1884 par MM. A. Letourneux, M. Sédillot et Valéry Mayet, membres de la mission de l'Exploration scientifique de la Tunisie. In: Exploration scientifique de la Tunisie. Imprimerie Nationale, Paris, pp. 1-55.

Simon, E. (1888) Etudes arachnologiques. 21e Mémoire. XXIX. Descriptions d'espèces et de genres nouveaux de l'Amérique centrale et des Antilles. Annales de la Sociét Entomologique de France, 8, 203-216.

Simon, E. (1898) Histoire naturelle des araignées, Tome 2. Librairie encyclopédique de Roret Paris, pp. 193-380.

Simon, E. (1910) Arachnoidea. Araneae (II). In: Schultze, L. (Ed.), Zoologische und anthropologische Ergebnisse einer Forschungsreise im Westlichen und zentralen Südafrika. Denkschriften der medizinisch- naturwissenschaftlichen Gesellschaft zu Jena, 16, 175-218.

Stratton, G.E., Hebets, E.A., Miller, P.R. \& Miller, G.L. (1996) Pattern and duration of copulation in Wolf Spiders (Araneae, Lycosidae). Journal of Arachnology, 24, 186-200.

Stratton, G.E., Suter, R.B. \& Miller, P. (2004) Evolution of water surface locomotion by spiders: a comparative approach. Biological Journal of the Linnean Society, 81, 63-78.

Sundevall, J.C. (1833) Conspectus Arachnidum. Londini Gothorum, pp. 1-39.

Thorell, T. (1877) Studi sui ragni Malesi e Papuani. I Ragni di Selebes raccolti nel 1874 dal Dott. O. Beccari. Annali di Museo Civico di Storia Naturale Genova, 10, 341-634.

Thorell, T. (1894) Decas aranearum in ins. Singapore a Cel. Th. Workman inventarum. Bollettino della Societ Entomologica Italiana, 26, 321-355.

Tullgren, A. (1905) Aranedia from the Swedish expedition through the Gran Chaco and the Cordilleras. Arkiv för Zoologi, 2(19), 1-81.

Vink, C.J. (2001) A revision of the genus Allotrochosina Roewer (Araneae: Lycosidae). Invertebrate Taxonomy, 15, 491466.

Vink, C.J. (2002) Lycosidae (Arachnida: Araneae). Fauna of New Zealand, 44, 1-94.

Vink, C.J., Mitchell, A.D. \& Paterson, A.M. (2002) A preliminary molecular analysis of phylogenetic relationships of Australasian wolf spider genera (Araneae: Lycosidae). Journal of Arachnology, 30, 227-237.

Vogel, B.R. (2004) A review of the spider genera Pardosa and Acantholycosa (Araneae, Lycosidae) of the 48 contiguous United States. Journal of Arachnology, 32, 55-108.

Yoo, J.-S. \& Framenau, V.W. (2006) Systematic and biogeography of the sheet-web bulding wolf spider genus Venonia (Araneae: Lycosidae). Invertebrate Systematics, 20, 675-712.

Zehethofer, K. \& Sturmbauer, C. (1998) Phylogenetic relationships of central European wolf spiders (Araneae: Lycosidae) inferred from 12S Ribosomal DNA sequences. Molecular Phylogenetics and Evolution, 10, $391-398$.

Zyuzin, A.A. (1985) [Generic and subfamilial criteria in the systematics of the spider family Lycosidae (Aranei), with the description of a new genus and two new subfamilies.] Trudy Zoologichesgogo Instituta, Akademia Nauk SSSR, 139, 40-51.

Zyuzyn, A.A. (1993) Studies on the wolf spiders (Araneae: Lycosidae). I. A new genus and species from Kazakhstan, with comments on the Lycosinae. Memoirs of Queensland Museum, 33, 693-700. 